\title{
Chloromonas nivalis subsp. tatrae, subsp. nov. (Chlamydomonadales, Chlorophyta): re-examination of a snow alga from the High Tatra Mountains (Slovakia)
}

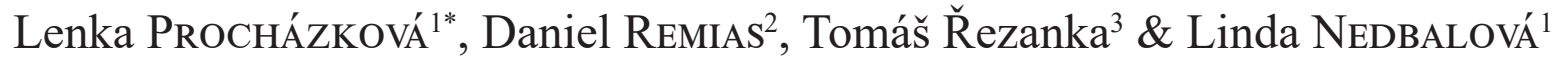

\author{
${ }^{1}$ Charles University, Faculty of Science, Department of Ecology, Viničná 7, CZ-128 44 Prague, Czech \\ Republic; Corresponding author e-mail: lenkacerven@gmail.com \\ ${ }^{2}$ University of Applied Sciences Upper Austria, Stelzhamerstraße 23, A-4600 Wels, Austria \\ ${ }^{3}$ Institute of Microbiology CAS, Videňská 1083, CZ-142 20 Prague, Czech Republic
}

\begin{abstract}
Melting snow fields populated by aplanozygotes of the genus Chloromonas (Chlamydomonadales, Chlorophyta) are found in polar and alpine habitats. In the High Tatra Mountains (Slovakia), cells causing blooms of brownish-red snow designated as Scotiella tatrae Kol turned out to be genetically (18S, ITS1 and ITS2 rDNA, $r b c \mathrm{~L}$ ) very closely related to Chloromonas nivalis (СНоDAT) НонAм et MulLet from the Austrian Alps. Therefore, Sc. tatrae is transferred into the latter taxon and reduced to a subspecies as Cr. nivalis subsp. tatrae. Both exhibit a similar photosynthetic performance, thrive in similar habitats at open sites above timberline, but differ in astaxanthin accumulation and number of aplanozygote cell wall flanges. In a field sample of Cr. nivalis subsp. tatrae, polyunsaturated fatty acids formed nearly $50 \%$ of total lipids, dominating in phospholipids and glycolipids. Cr. nivalis subsp. tatrae represents likely a variation of a common cryoflora species with distinct morphology.
\end{abstract}

Key words: aplanozygote, astaxanthin, Chloromonas nivalis, fatty acids, field sample, High Tatra Mountains, photosynthesis, snow algae, Scotiella, ultrastructure

\section{INTRODUCTION}

Snow inhabiting algae are polyextremophiles in terms like habitat temperature, incident irradiation or availability of liquid water and nutrients. They have been reported from many mountainous and polar regions, where melting snow packs persist until summer (Hoham \& Duval 2001). Cryoflora draws attention not only because of greenish to reddish snow discolorations, but also due to striking morphologic and physiologic strategies in course of its adaptation (KOMÁREK \& NedBALoví 2007), especially in comparison with their 'conventional' mesophilic relatives. CVETKOVSKa et al. (2016) summarized the evolutional origin and diversity of psychrophilic algae, showing that Chlorophyta harbour more than a third of all known photo-psychrophiles (plastid-bearing protists metabolically active and able to reproduce at temperatures permanently close to the freezing point of water, which do not tolerate temperatures $>20^{\circ} \mathrm{C}$ ). Generally, psychrophiles occur in a great variety of habitats and exhibit strategies like anti-freeze proteins or accumulation of compatible solutes like glycine (DE MAAYER et al. 2014).
The Tatra Mountains, which are located mainly in northern Slovakia and to a smaller part in southern Poland, are the topmost part of the Carpathian Arc. The relief of this mountain range is very complex due to glacial events (ZASADNI \& KŁAPYTA 2014). The presence of red snow in the Tatra Mountains was already reported several centuries ago (BuchHolz 1783). The high cryoflora biodiversity of this massif was summarized by KoL (1975a, b).

The genus Scotiella (Sc.) was established by FritsCH (1912) with the snow alga Sc. antarctica FRITSCH as the type. It is characterized by striking cell wall surface structures like flanges, and daughter cells were said to possess the same ribbed morphology already before being released from the mother cell. Many fusiform snow algae inhabiting polar areas and high alpine zones were initially believed to be a member of this genus (Kol 1968). However, the true nature of Scotiella-stages as aplanozygotes ('aplano-'= immotile according to ETTL \& GäRTNER 2014) in the life cycle of a Chloromonas ( $\mathrm{Cr}$.)-like flagellate was revealed decades after the initial description by Нонам \& Mullet (1977), who showed that vegetative daughter 
cells lack any cell wall ornamentation. Thus, several Scotiella like species inhabiting snow were transferred to the genus Chloromonas (HoHAm \& Mullet 1978), e.g. Sc. antarctica was considered to be a zygotic stage of $\mathrm{Cr}$. nivalis (CHODAT) HoHAM \& Mullet, however the synonymy has been later questioned due to different cell flange morphology between these two species (Novis 2002). The genus Scotiella is now regarded as an artificial group of species retained for those taxons which's reproduction is unknown (Hanagata 1998).

In this work, we studied populations collected close to the type locality of Sc. tatrae in the High Tatras, more than 50 years after the initial description by KoL (1965). All investigations were undertaken with field material, since cultures are not available yet, most likely because continuous growth under laboratory conditions was, to our knowledge, so far unsuccessful. The overall aim of this study was to evaluate abiotic habitat parameters, to check the phylogenetic position of Sc. tatrae using molecular and morphological traits, to measure the photosynthetic activity under varying light conditions, to describe the pigments which cause the secondary reddish colouration and finally, taking a putative adaptation to low temperatures into account, analysing the repertoire of fatty acids (FAs) occurring in membranes and cellular lipid depots.

The results were compared with the closest relatives, which is especially $C r$. nivalis, from snow fields in the Austrian Alps.

\section{Material ANd Methods}

Sampling and snow characteristics. The cryoflora of brownish-red snow fields in the High Tatra Mts. (Slovakia) was investigated in June 2016 (Fig. 1). Exact geographic position, sampling date, elevation and corresponding sample code are summarized in Table 1. Surface snow samples were harvested either with a sterile plastic shovel and a 101 bucket (sample 'LP01') or directly transferred into $50 \mathrm{ml}$ sterile plastic tubes (other two samples). Samples were transported the same day to a field laboratory in close proximity. Prior to physiological measurements, the snow was gently melted over night at $4{ }^{\circ} \mathrm{C}$ to $5{ }^{\circ} \mathrm{C}$ and kept in its own melt water in the dark.

Electrical conductivity (EC) and $\mathrm{pH}$ of melt water samples were obtained with HANNA (Combo EC, Romania) and WTW Instruments (Inolab pH, Germany), respectively. Snow density was measured by coring snow with a cylindrical polyvinylchloride corer (length $72 \mathrm{~cm}$, diameter $3.7 \mathrm{~cm}$, volume 0.7741 ). All cores were taken in the layer visually containing a bloom of snow algae and were orientated parallel to the surface of the snowbank according to Нонам (1975). Cores were then transferred into plastic bags and the weight of each core was immediately measured by a spring balance Medio Line (precision 2 g, Pesola, Switzerland; similarly to KŘísteK et al. 2011). Three independent random cores were averaged. The snow water content (SWC) was expressed in percent and calculated as (weight of a snow core divided by the weight of water of the same volume as the core) $\times 100$.
Light and electron microscopy. Light microscopy (LM) was conducted using an Olympus BX43 (Olympus corporation, Japan) equipped with a digital camera DXM 1200F (Nikon, USA). Microphotographs were processed using the QuickPHOTO Camera 3.0 software (Promicra, Czech Republic). The same software was used to measure cell sizes. Preparation of samples for scanning and transmission electron microscopy (SEM and TEM, respectively) included joint steps: samples were fixed in $1.25 \%$ glutaraldehyde in $50 \mathrm{mM}$ cacodylate buffer $(\mathrm{pH} 7.0)$ for 2 hours at $4{ }^{\circ} \mathrm{C}$, two times washed in cacodylate buffer at $4{ }^{\circ} \mathrm{C}$ for 15 minutes, postfixed in $1 \% \mathrm{OsO}_{4}$ overnight at $4{ }^{\circ} \mathrm{C}$, three times washed in distilled water, gradually dehydrated through an ascending ethanol series (until $70 \%$ ethanol in $4{ }^{\circ} \mathrm{C}$, then switched to room temperature). For SEM, fixed cells were transferred into a critical point drying chamber (Bal-Tec CPD 030). After gold-coating, specimens were examined with a JEOL $6380 \mathrm{LV}$ SEM at $25 \mathrm{kV}$. For TEM, cells were embedded in Araldine and Poly/Bed ${ }^{\circledR} 812$ mixture (SPI-CHEM, USA). Ultrathin sections were cut with a diamond knife, stained using uranyl acetate and lead citrate. TEM grids were examined with a JEOL 1011 TEM (JEOL Ltd., Japan) at 80 $\mathrm{kV}$. Microphotographs were taken with a Veleta CCD camera equipped with Olympus image analysis software (Olympus Soft Imaging Solution, Germany) and later modified by iTEM 5.1 (Germany Soft Imaging Solution, Germany).

Cell counting and cultivation. A $10 \mathrm{ml}$ subsample was taken at Capie Lake shore snow field (location LP01) in order to determine the cell concentration. After snow melt and homogenisation by shaking, a subsample of $0.01 \mathrm{ml}$ was put into a Cyrus I chamber (Meopta, Czech Republic) for counting under a light microscope. Two replicates were analysed, each with a grid area of $1 \mathrm{~cm}^{-2}$. More than 200 cells were counted for one run. Attempts were made to culture the dominating snow algal species. For this, cells were placed a day after sampling on petri dishes containing BBM medium $1.5 \%$ agar (BISCHOFF \& BOLD 1963) and kept at $3{ }^{\circ} \mathrm{C}$ under continuous illumination of $20 \mu$ mol.photons. $\mathrm{m}^{-2} \cdot \mathrm{s}^{-1}$. Light

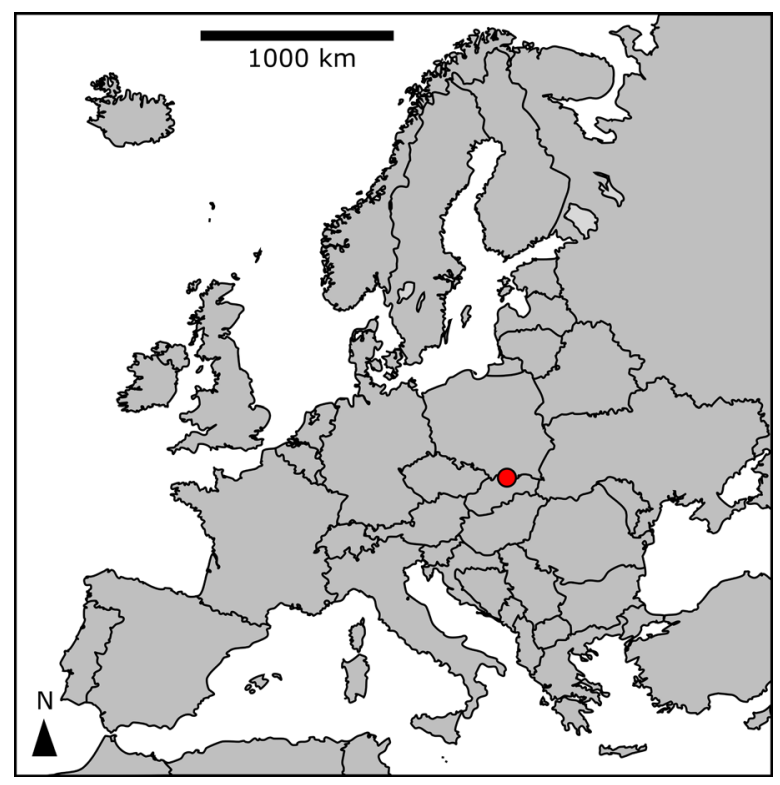

Fig. 1. Location of the High Tatra Mountains, Slovakia (marked with a red circle). 
Table 1. Samples of Chloromonas nivalis subsp. tatrae from the High Tatra Mountains with sample codes, collection date, sampling site, altitude (m a.s.1.) and geographic position (GPS).

\begin{tabular}{lllll}
\hline Sample/reference & Date & Location & Altitude & GPS \\
\hline LP01 (this study) & 18 June 2016 & shore of Capie Lake & 2073 & N49॰10.081 E20 02.279 \\
KoL (1965) & 22 June 1932 & shore and ice cover of Okrúhle Lake & 2000 & N49¹0.242 E20 02.178 \\
\hline
\end{tabular}
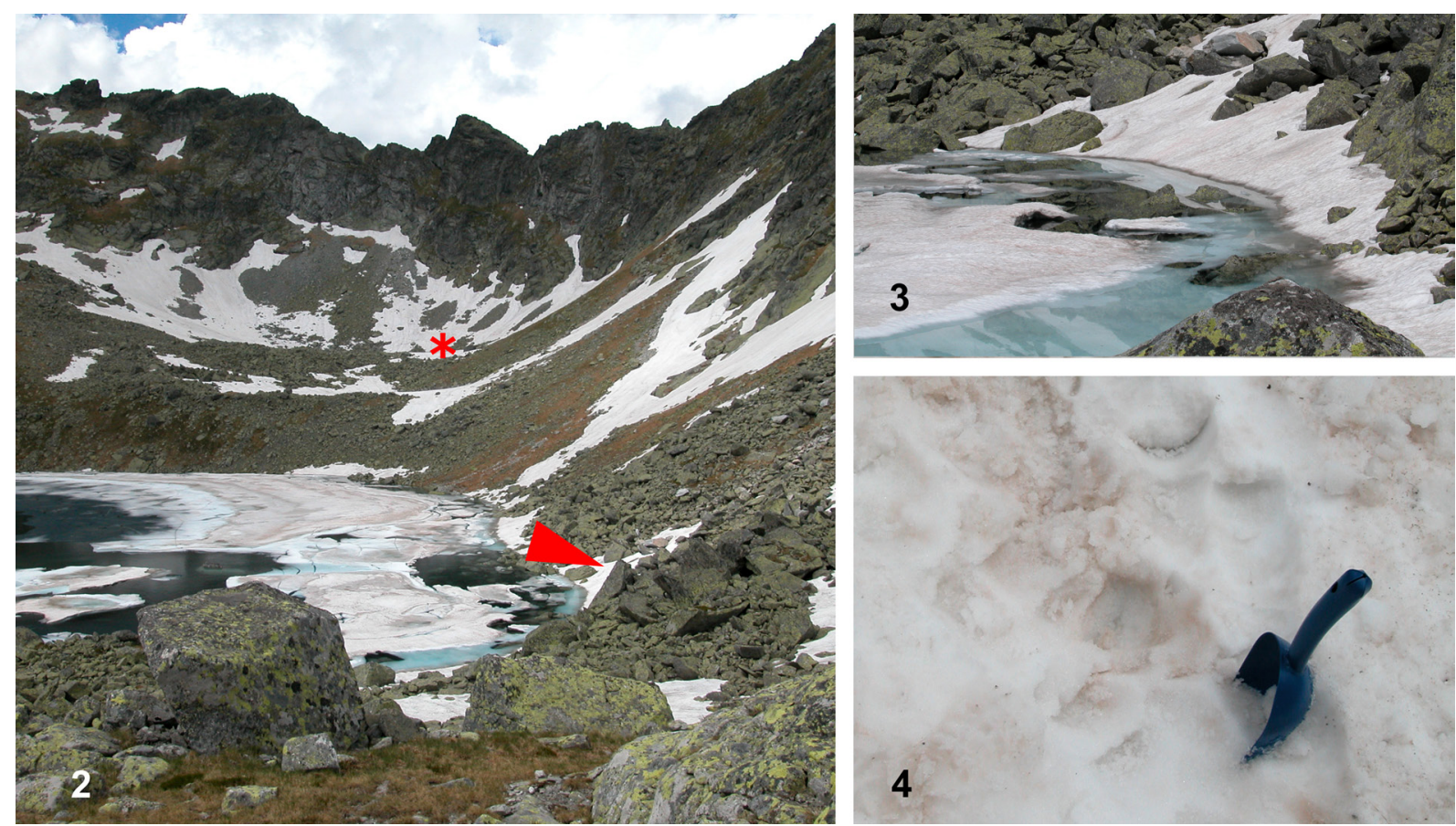

Fig. 2-4. Overview of sampling sites of Chloromonas nivalis subsp. tatrae: (2) sampling location of this study next to Capie Lake (code LP01, red arrowhead) and the first observation in 1932 in Okrúhle Lake (asterisk); (3) coloured snowfields at LP01 (4) detail view of brownish-red snow after harvest.

microscopy of field samples kept in their original meltwater was performed $\sim 100$ days after sampling to verify the development of daughter cells.

Isolation of DNA, sequencing, ITS2 rRNA secondary structure prediction and phylogenetic analysis. DNA was isolated from the sample LP01 with a DNeasy Plant Mini Kit (Qiagen). Cells were mechanically disrupted by shaking for $15 \mathrm{~min}(30 \mathrm{~Hz})$ in the presence of glass beads ( $3 \mathrm{~mm}$ diameter, Sigma-Aldrich) in a Mixer Mill MM 400 (Retsch, Germany). Then, samples were put in freezer at $-20{ }^{\circ} \mathrm{C}$ for half an hour. Subsequently, DNA was isolated in accordance with the manufacturer's procedure. Quality and concentration of DNA was measured on the NanoDrop ${ }^{\circledR}$ ND1000 Spectrophotometer (NanoDrop Technologies, Inc.).

The 18S small subunit ribosomal RNA gene (18S rDNA), internal transcribed spacer regions 1 and 2 (ITS1, ITS2 rDNA) and ribulose-1,5-bisphosphate carboxylase/ oxygenase large subunit $(r b c \mathrm{~L})$ gene regions were amplified from DNA isolates by PCR using existing primers (Table 2). Amplification reactions for $18 \mathrm{~S}$ rDNA was performed using cycle parameters according to KATANA et al. (2001) with minor modification that duration of initial denaturation was prolonged for $10 \mathrm{~min}$ and annealing temperatures were
$50{ }^{\circ} \mathrm{C}, 58^{\circ} \mathrm{C}$ and $61^{\circ} \mathrm{C}$. Amplification reactions for $r b c \mathrm{~L}$ gene were performed using cycle parameters according to HoHAM et al. (2002) with minor change that three different annealing temperatures were applied $\left(53^{\circ} \mathrm{C}, 55^{\circ} \mathrm{C}, 59^{\circ} \mathrm{C}\right)$. Each $20 \mu \mathrm{l}$ of PCR reaction for $18 \mathrm{~S}$ and $r b c \mathrm{~L}$ amplification contained $5 \mu \mathrm{l}$ of DNA isolates (diluted to concentration of $5 \mathrm{ng} . \mu \mathrm{l}^{-1}$ ), $0.8 \mu \mathrm{l}$ of each $10 \mu \mathrm{M}$ primer, $1.6 \mu 1$ of $25 \mathrm{mM} \mathrm{MgCl}, 1.5$ $\mu 1$ of $2 \mathrm{mM}$ dNTPs, $2 \mu 1$ of $10 \times$ Taq buffer $+\mathrm{KCl}-\mathrm{MgCl}_{2}$, $7.8 \mu 1$ sterile Milli-Q water, and $0.5 \mu 1$ of $1 \mathrm{U}^{-} \mu \mathrm{l}^{-1}$ Taq DNA polymerase (Fermentas, USA). Amplification reactions for ITS2 rDNA region were performed using cycle parameters according to GoFF \& Moon (1993) with minor modification that the gradient of annealing temperature was included $\left(56{ }^{\circ} \mathrm{C}, 58{ }^{\circ} \mathrm{C}, 61^{\circ} \mathrm{C}, 64^{\circ} \mathrm{C}\right)$. Each $35 \mu 1 \mathrm{PCR}$ reaction contained $1 \mu \mathrm{l}$ of DNA isolates (diluted to concen-

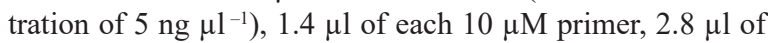
$25 \mathrm{mM} \mathrm{MgCl}_{2}, 2.6 \mu \mathrm{l}$ of $2 \mathrm{mM}$ dNTPs, $3.5 \mu \mathrm{l}$ of $10 \times$ buffer Taq buffer $+\mathrm{KCl}-\mathrm{MgCl}_{2}, 21.8 \mu \mathrm{l}$ sterile Milli-Q water, and $0.5 \mu 1$ of $1 U . \mu 1^{-1}$ Taq DNA polymerase (Fermentas). The PCR products were stained with bromophenol loading dye, quantified on $1.5 \%$ agarose gel, stained with GelRed. The amplification products were purified and sequenced using an Applied Biosystems automated sequencer (ABI 3730×1) at Macrogen (Korea). The newly obtained sequences were 
Table 2. List of primers used for amplification of $18 \mathrm{~S}$ rDNA, ITS1 rDNA, ITS2 rDNA (ITS) and $r b c$ L markers; (F) forward; (R) reverse.

\begin{tabular}{|c|c|c|c|c|}
\hline Primer & Marker & Direction & Sequence & Reference \\
\hline SSU & ITS & $\mathrm{F}$ & CTGCGGAAGGATCATTGATTC & PierceY-Normore \& DePriest (2001) \\
\hline LSU & ITS & $\mathrm{R}$ & AGTTCAGCGGGTGGTCTTG & Piercey-Normore \& DePriest (2001) \\
\hline Al1500af & ITS & $\mathrm{F}$ & GCGCGCTACACTGATGC & HeLms et al. (2001) \\
\hline LR3 & ITS & $\mathrm{R}$ & GGTCCGTGTTTCAAGACGG & ViLGALyS \& Hester (1990) \\
\hline rbcL1F & $r b c \mathrm{~L}$ & $\mathrm{~F}$ & CTGCTTTATACTGCGAAACTGC & Нонам et al. (2002) \\
\hline rbcL7R & $r b c \mathrm{~L}$ & $\mathrm{R}$ & AAATAAATACCACGGCTACG & Нонам et al. (2002) \\
\hline rbcL10F & $r b c \mathrm{~L}$ & $\mathrm{~F}$ & GGTAACGTWTTTGTTTCAAAGC & Нонам et al. (2002) \\
\hline rbcL14R & $r b c \mathrm{~L}$ & $\mathrm{R}$ & CGTTCWCCTTCAAGTTTACC & Нонам et al. (2002) \\
\hline rbcL19F & $r b c \mathrm{~L}$ & $\mathrm{~F}$ & CTCAATCGTTCATGCGTTGG & Нонам et al. (2002) \\
\hline rbcL4R & $r b c \mathrm{~L}$ & $\mathrm{R}$ & GAAAATGAAACGGTCTCTCC & Нонам et al. (2002) \\
\hline $18 \mathrm{~S} 1 \mathrm{~F}$ & $18 \mathrm{~S}$ & $\mathrm{~F}$ & CTGCTTTATACTGCGAAACTGC & Нонам et al. (2002) \\
\hline $34 \mathrm{~F}$ & $18 \mathrm{~S}$ & $\mathrm{~F}$ & GTCTCAAAGATTAAGCCATGC & MikHAILYUK et al. (2008) \\
\hline $895 \mathrm{R}$ & $18 \mathrm{~S}$ & $\mathrm{R}$ & AAATCCAAGAATTTCACCTC & MiKHAILYUK et al. (2008) \\
\hline $18 \mathrm{~F}$ & $18 \mathrm{~S}$ & $\mathrm{~F}$ & AACCTGGTTGATCCTGCCAGT & KatANA et al. (2001) \\
\hline $18 \mathrm{R}$ & $18 \mathrm{~S}$ & $\mathrm{R}$ & TGATCCTTCTGCAGGTTCACCTACG & KATANA et al. (2001) \\
\hline $1122 \mathrm{R}$ & $18 \mathrm{~S}$ & $\mathrm{R}$ & CAATTCCTTTAAGTTTCAGCC & MikHAILYUK et al. (2008) \\
\hline
\end{tabular}

submitted to NCBI Nucleotide sequence database (accession numbers for Cr. nivalis subsp. tatrae LP01: 18S, ITS1, ITS2 - KY499614, rbcL - KY499615; Cr. nivalis P24/DR4: rbcL - KY499616).

The nuclear rDNA ITS2 region was identified using a web interface at the ITS2 database showing position of $5.8 \mathrm{~S}$ and 26S motives (http://its2.bioapps.biozentrum.uni-wuerzburg.de/cgi-bin/index.pl?annotator; KoETSCHAN et al. 2010). The sequence was then folded with 5.8S-LSU stem regions using the Mfold server accessible at http://mfold.rna.albany. edu/?q5mfold (ZuKer 2003). A model of the secondary structure consistent with the specific features of nuclear rDNA ITS2 was selected: four helixes, U-U mismatch in helix II, and the UGGU motif near the $5^{\prime}$-end site apex of helix III (COLEMAN 2007).

Photosynthesis. In vivo chlorophyll fluorescence parameters were obtained in a chamber for liquid samples at approximately $0{ }^{\circ} \mathrm{C}$ with a pulse-amplitude modulated fluorometer (PAM 2000, Heinz Walz GmbH, Germany). To gain sufficient biomass, cells were concentrated by passive sedimentation of melt water in a 11 plastic cylinder overnight and the pellet was then used for measurements. Prior measurement, algae were kept in the snow meltwater in the dark for 30 minutes. Then, cells were exposed to photon flux densities (PFDs) of 5, 34, 66, 104, 201, 366, 622, 984, 1389, 1666 and $2018 \mu \mathrm{mol}$.photons. $\mathrm{m}^{-2} . \mathrm{s}^{-1}$ for 30 seconds each. Four replicate measurements were carried out. After each light exposure, a saturating pulse was given to detect effective photochemical quantum yield of photosystem II (PS II):

$\mathrm{Y}(\mathrm{II})=\left(\mathrm{F}_{\mathrm{m}}{ }^{\prime}-\mathrm{F}\right) / \mathrm{F}_{\mathrm{m}}{ }^{\prime}($ GeNTY et al., 1989)

where $\mathrm{F}_{\mathrm{m}}{ }^{\prime}=$ maximal fluorescence yield emitted by chlorophyll-a in PS II when PSII reaction centres are closed by a saturation pulse and $\mathrm{F}=$ minimum fluorescence yield at steady state.

Afterwards, the relative electron transport rate of PSII (rETR) was calculated as follows:

$\mathrm{rETR}=\mathrm{Y}(\mathrm{II}) \times \mathrm{PFD} \times \mathrm{P}_{\mathrm{PSII}} / \mathrm{P}_{\mathrm{PPS}} \times$ ETR-Factor

where $\mathrm{Y}(\mathrm{II})=$ the effective PSII quantum efficiency, PFD = photon flux density, $\mathrm{P}_{\mathrm{PSII}} / \mathrm{P}_{\mathrm{PPS}}=$ photons absorbed by PS II relative to photons absorbed by all photosynthetic pigments (default value 0.5$),$ ETR-Factor $=$ an empirical corrective factor (default value 0.84), which considers fraction of incident photons absorbed by the chlorophyll $a$ molecules in PSII.

A curve of rETR upon PFD was calculated and fitted by the mathematical model according to WALSBY (1997) where photoinhibition is assumed. Presence of photoinhibition was indicated by $\beta<0$ :

$\mathrm{rETR}=\mathrm{ETR}_{\max }\left(1-\exp \left(-\alpha \times \mathrm{PFD} / \mathrm{ETR}_{\max }\right)\right)+\beta \times \mathrm{PFD}$

where $\mathrm{rETR}=$ relative electron transport rate of PSII, $\mathrm{rETR}_{\max }$ $=$ maximum relative electron transport rate of PSII, $\alpha=$ initial slope alpha and $\beta=$ slope of the curve at high irradiances. $\mathrm{PFD}=$ photon flux density. The parameters $\mathrm{ETR}_{\max }, \alpha$ and $\beta$ were found using the Solver software in Microsoft Excel.

If $\beta>0$ (no photoinhibition), curve of rETR upon PFD was calculated and fitted according to model WeBB et al. (1974) where photoinhibition is not assumed: 
$\mathrm{rETR}=\mathrm{ETR}_{\text {max }}\left(1-\exp \left(-\alpha \times \mathrm{PFD} / \mathrm{ETR}_{\text {max }}\right)\right)$

The fitting model with a lower sum of squared deviations was chosen.

Pigment analysis. Chlorophylls and carotenoids were isolated and determined by a protocol optimized for snow algae described by Remias \& LüTZ (2007) and Remias et al. (2013). Briefly, cells were lyophilized on glass fibre filters and broken in a shaking mill and using quartz balls and mill jars precooled with liquid nitrogen. Extraction was performed with dimethylformamide (Sigma-Aldrich) and compounds were identified and quantified by high performance liquid chromatography with diode array detector (Agilent ChemStation 1100).

Lipid extraction. The extraction procedure was based on the method of BLIGH \& DYER (1959), except that 2-propanol was substituted for methanol, since 2-propanol does not serve as a substrate for phospholipases (KATES \& VOLCANI 1996). The alcohol-water mixture was cooled, one part chloroform was added and the lipids from the lyophilized cells were extracted for $30 \mathrm{~min}$. Insoluble material was sedimented by centrifugation and the supernatant was separated into two phases. The aqueous phase was aspirated off and the chloroform phase was washed three times with two parts $1 \mathrm{M} \mathrm{KCl}$ each. The resulting chloroform phase was evaporated to dryness under reduced pressure. $10 \mathrm{mg}$ of total lipid extract in $1 \mathrm{ml}$ of chloroform was applied to Sep-Pak Vac Silica cartridge $35 \mathrm{cc}$ (Waters; $10 \mathrm{~g}$ normal-phase silica), and then eluted with $30 \mathrm{ml}$ each of the following solvents: chloroform (neutral lipids), acetone (glycolipids), and methanol (phospholipids) at $4 \mathrm{ml} \mathrm{min}^{-1}$ (SAUNDERS \& Horrocks 1984). The eluates of each lipid class were then evaporated prior further analysis.

Fatty acid methyl esters analysis (FAMEs). The lipids (neutral lipids, glycolipids and phospholipids) ( $\sim 5 \mathrm{mg}$ of total dry weight) were saponified overnight in $10 \% \mathrm{KOH}-\mathrm{MeOH}$ at room temperature. A FA fraction obtained from saponification was partitioned between alkali solution $(\mathrm{pH} 9)$ and diethylether to remove basic and neutral components. The aqueous phase, containing FAs, was acidified to $\mathrm{pH} 2$ and extracted with hexane. The FA fraction was methylated using $\mathrm{CH}_{2} \mathrm{~N}_{2}$. Gas chromatography coupled with mass spectrometry (GCMS) of FAMEs mixture was done on a Finnigan $1020 \mathrm{~B}$ with electron ionization (EI) mode. Splitless injection was at 100 ${ }^{\circ} \mathrm{C}$, and a fused silica capillary column (Supelcowax 10; 60 $\mathrm{m} \times 0.25 \mathrm{~mm}$ i.d., $0.25 \mathrm{~mm}$ film thickness; Supelco, Prague) was used. The temperature program was as follows: $100^{\circ} \mathrm{C}$ for $1 \mathrm{~min}$, subsequently increasing at $20^{\circ} \mathrm{C} \mathrm{min}^{-1}$ to $180{ }^{\circ} \mathrm{C}$ and at $2{ }^{\circ} \mathrm{C} \mathrm{min}-1$ to $250^{\circ} \mathrm{C}$, which was maintained for $1 \mathrm{~min}$.
The carrier gas was helium at a linear velocity of $60 \mathrm{~cm} \cdot \mathrm{s}^{-1}$. All spectra were scanned within the range of $\mathrm{m} / \mathrm{z} 50-500$. The structures of FAMEs were confirmed by comparison of retention times and fragmentation patterns with those of stan-

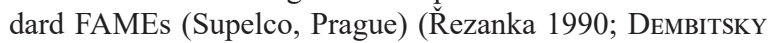
et al. 1991).

Statistical analysis. Cell sizes (length, width, length to width ratio) of $S c$. tatrae (LP01) were compared with those from Cr. nivalis at the Austrian Alps, (P12, P24/DR4, DR43, GK05, GK09; collection data of these field samples in Table S1 and in Remias et al. 2010). Kruskal-Wallis test was used for testing the hypothesis that cell size median of all $\mathrm{Cr}$. nivalis samples from the Austrian Alps is not different. Moreover, Mann-Whitney test was used for testing the hypothesis that the median of two groups is identical (Sc. tatrae vs. Cr. nivalis).

\section{ReSUlTS}

\section{Collection sites and habitat conditions}

In the High Tatra Mountains (Slovakia), brownish-red snow fields were found during June 2016 at elevations of approximately $2000 \mathrm{~m}$ a. s. 1. (Figs 2-4). A site in the vicinity to the locality of the first observation of the snow alga $S c$. tatrae was sampled: the coloured snow was harvested at the shore of Capie Lake in Mlynická Valley (sample LP01) (Table 1). The population contained virtually only cells with a morphology according to Sc. tatrae. Scattered cells of the fungi Chionaster nivalis BoHLIN (WILlE) occurred. The habitat conditions of this locality are shown in Table 3. Moreover, snowfields dominated mainly by morphotype $C r$. nivalis and rarely of $S c$. tatrae were found in other sampling spots slightly distant from the Okrúhle Lake (at the shore of Vyšné Kozie Lake in Mlynická Valley - $0.5 \mathrm{~km}$ far away; at the shore of Upper Sesterske Lake in Velká Studená Valley - about $10 \mathrm{~km}$ far away).

\section{Morphology and ultrastructure}

Cell wall surface and intercellular organisation of field samples was described by light and electron microscopy (Figs 5-27). The fusiform cells of Sc. tatrae were taxonomically determined by their characteristic surface structures, and the harvested cell stage was tentatively designated as an aplanozygote on the basis of the life cycle proposed by Hoham \& Mullet (1977). The

Table 3. Abiotic habitat parameters and cell sizes of Chloromonas nivalis subsp. tatrae field samples from the High Tatra Mountains. Electrical conductivity $\left(\mathrm{EC} ; \mu \mathrm{S} . \mathrm{cm}^{-1}\right), \mathrm{pH}$ of meltwater and snow water content (SWC; \%), population density $\pm \mathrm{SD}$ (standard deviation), average sizes of cells in $\mu \mathrm{m} \pm \mathrm{SD}$, length to width ratio (L:W ratio) $\pm \mathrm{SD}$ and number of cell wall flanges counted at equatorial region of cell in cross-section view are shown.

\begin{tabular}{lcccccccc}
\hline Sample/reference & EC & pH & SWC & $\begin{array}{l}\text { cells per ml cell length } \\
\text { meltwater }\end{array}$ & cell width & L:W ratio & flanges \\
\hline LP01 (this study) & 15 & 5.7 & $52.6 \pm 3.8$ & $19950 \pm 1995$ & $19.8 \pm 1.3$ & $12.8 \pm 0.9$ & $1.55 \pm 0.12$ & $(9) 10-12(14)$ \\
KOL (1965) & - & 5.2 & - & - & $18-24$ & $12-15$ & - \\
\hline
\end{tabular}


5

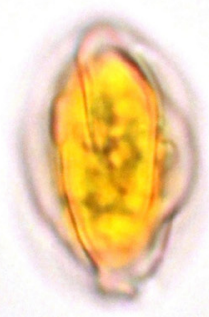

6
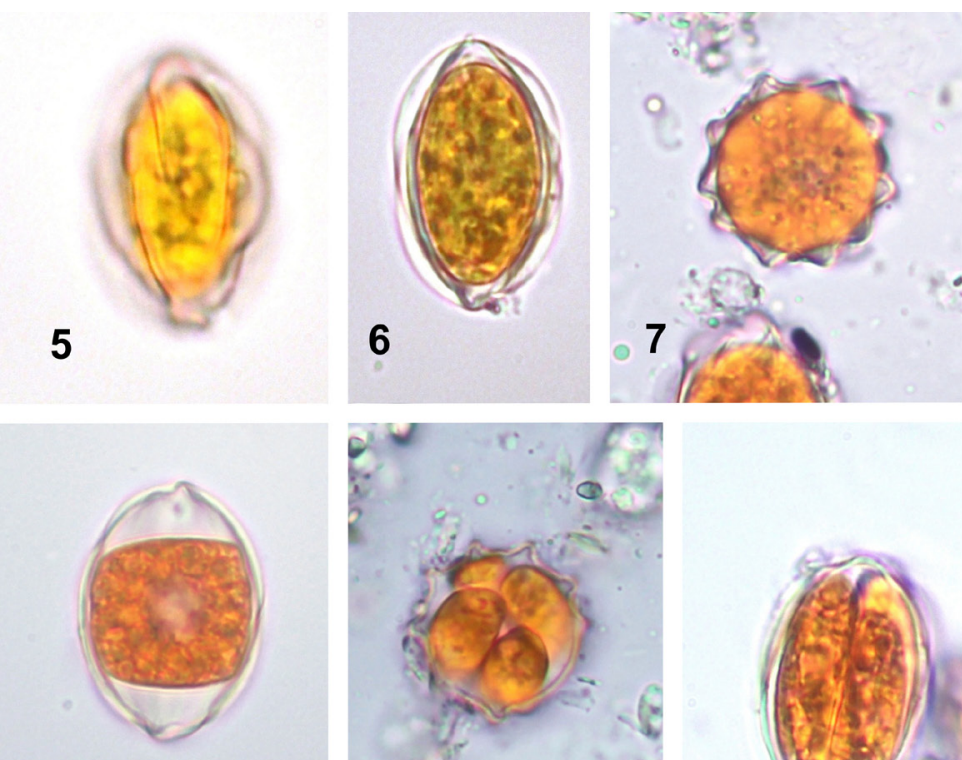

10
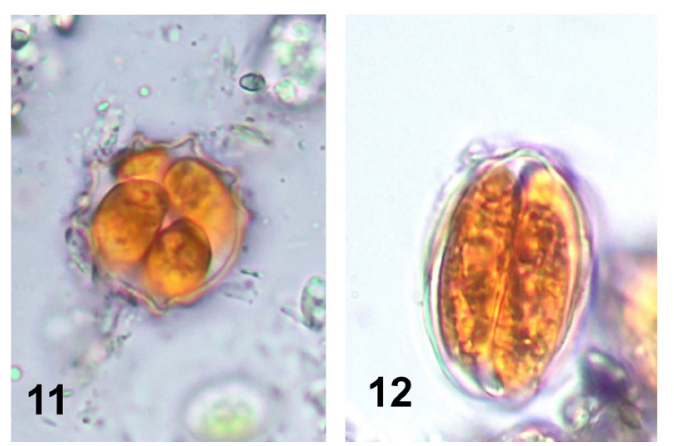
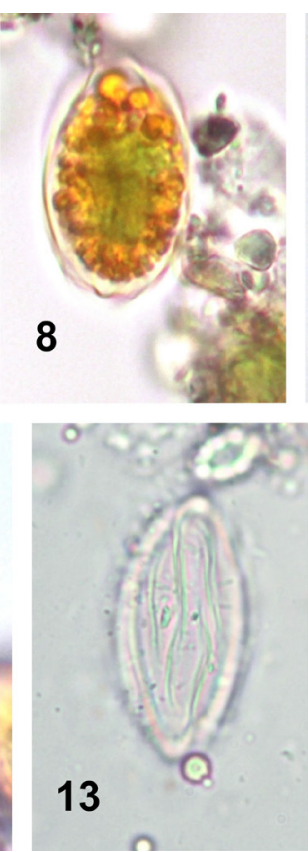
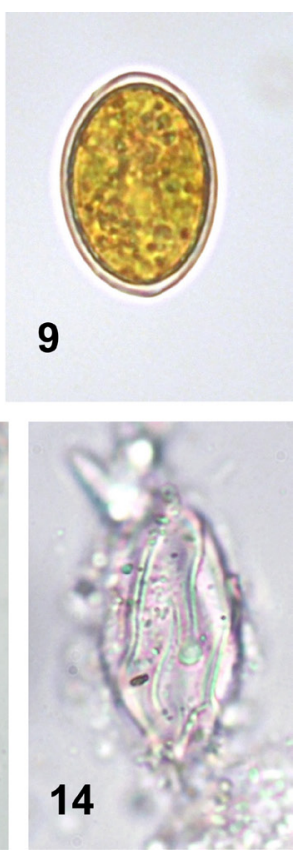

Figs 5-14. LM micrographs of Chloromonas nivalis subsp. tatrae subsp. nov.: (5-9) mature aplanozygotes which dominated the field sample, (5-6) cell wall flanges, (7) focus at cross section view of cells in upright position, showing 10 cell wall flanges, (8) cytoplasm containing peripheral reddish astaxanthin depots and central greenish spots of the chloroplast, (9) young aplanozygotes with smooth cell walls were rarely present; (10), old' cells, preparing for division (most likely meiotic) by contracting the protoplast after being kept in original meltwater for $\sim 100$ days; (11-12) in a subsequent step, four elongate daughter cells were developed, still surrounded by the mother cell wall, (11) apical and (12) lateral view of the smooth walled daughter cells; (13-14) empty secondary cell walls showing (13) straight and (14) slightly undulating cell flanges. Scale bar $20 \mu \mathrm{m}$.

ornamented cell wall structures were made of straight to sometimes slightly undulated flanges (Figs 5-6, 13-14), and LM showed that (9)10-12(14) flanges per cell were present in equatorial region, which became evident at cross-section view (Fig. 7). The average cell sizes are summarised in Table 3. The cytoplasm was almost entirely occupied by lipid bodies containing a secondary pigmentation, thus causing an overall orange impression of the cells (Fig. 8). Rarely, young aplanozygotes surrounded by a smooth (primary) cell wall were observed (Fig. 9). SEM confirmed the presence of 10 to 14 flanges (Fig. 18), and further details of their arrangement could be observed: most common were flanges reaching from pole to pole (Fig. 15) and from one pole nearly to the antapex (Fig. 16). Rarely, flanges reached from one pole only to the equatorial position of the cell (Fig. 16), bifurcations (Fig. 17) or isolated shorter flanges (Fig. 15) also occurred. In a few cases all these secondary surface structures were found on a single aplanozygote. The ultrastructure observed by TEM is presented in Figs 19-27. Three different life cycle stages were recognized. Firstly, ovoid young aplanozygotes still without cell wall flanges, usually with one compact chloroplast containing starch grains (Fig. 19). In a few cases, an undulated cell membrane was found (Fig. 19). Moreover, mitochondria were observed (Fig. 20). Well-developed Golgi bodies and a cytoplasm rich in vesicles and ribosomes indicated an active metabolism (Fig. 21). Vacuoles full of electron dense, sometimes crystalline content were also present
(Fig. 21). Secondly, intermediate aplanozygotes with flanges at the secondary cell wall surface, but still surrounded by a primary cell wall were observed (Figs 22-25). Thirdly, and prevailing in the sample, 'mature' aplanozygotes with fully developed flanges. The majority of the cytoplasmatic volume was occupied by large lipid bodies (containing secondary pigments) (Figs. 26-27). Instead of a compact chloroplast, several smaller spherical plastids located around the nucleus were present. Starch grains were very small or absent. Other life cycle stages like vegetative flagellates or any cleaving activities (formation of daughter cells) were not observed directly after sampling.

In order to discriminate $S$ c. tatrae from its' closest relative, $\mathrm{Cr}$. nivalis from the Austrian Alps, cell sizes of aplanozygotes of both snow algae were compared. Sc. tatrae aplanozygotes were significantly smaller in term of cell length (17.6-23.1, median 19.5 vs. $18.35-27 \mu \mathrm{m}$, median 22.4$)$, width (10.9-16.2, median 12.9 vs. $10.6-16 \mu \mathrm{m}$, median 13.2) and length to width ratio (1.33-1.8, median 1.55 vs. $1.38-2.04$, median 1.7) (Figs S1-S4). However, significant differences in cell sizes were found also among samples of Cr. nivalis (Table. 4).

\section{Population density and cultivation assay}

The population density of Sc. tatrae (LP01) was 19 $950 \pm 1995$ cells. $\mathrm{ml}^{-1}$ meltwater (Table 3). Cultivation assays were unsuccessful, and no cell cleavages have been observed up to three months after inoculation on 

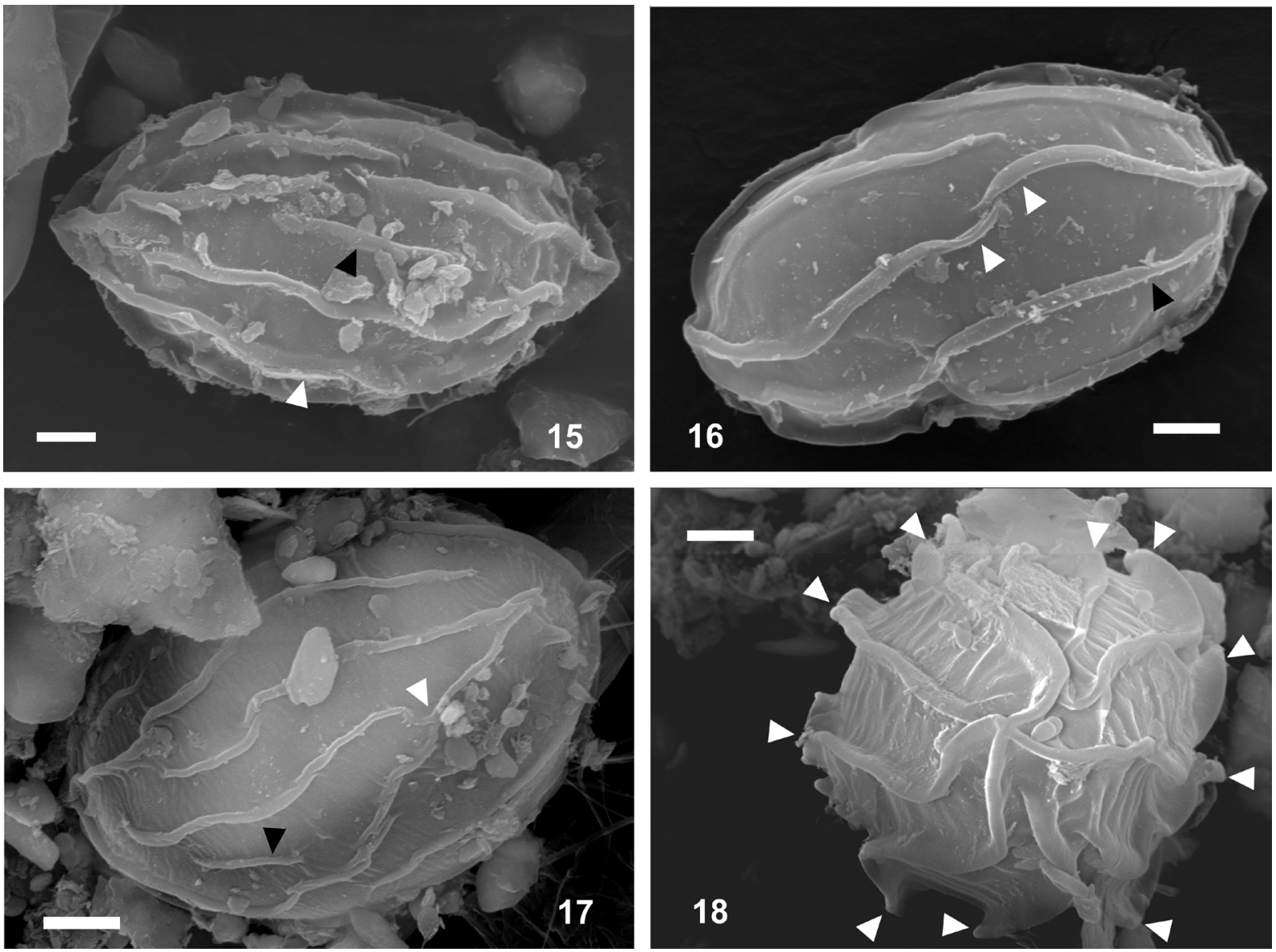

Figs 15-18. SEM micrographs of mature aplanozygotes of Chloromonas nivalis subsp. tatrae subsp. nov.: (15) cell wall flange reaching from pole to pole (white arrow) and an isolated short flange (black arrow); (16) the flange reaches from pole nearly to antapex (black arrow) and two flanges are reaching from opposite cell poles and finally touching at the equatorial region of the cell (white arrows); (17) two flanges join together, respectively a bifurcation of one flange into two independent is shown (white arrow), moreover, an isolated short flange is present (black arrow); (18) apical view of a cell presenting 10 flanges in total (white arrows). Scale bars $2 \mu \mathrm{m}$.

solid medium. However, in a field sample kept in its original meltwater for approximately 100 days, many cells started to contract the protoplast (Fig. 10) and to generate four elongate daughter cells $(4.5-6.7 \mu \mathrm{m}$ wide $\times 15.4-20.4 \mu \mathrm{m}$ long), still surrounded by the mother cell wall (Figs 11-12). The constant number of four daughter cells points to foregoing meiotic divisions. The daughter cell pigmentation was similarly orangegreenish like that of the mother cell before cleavage.

\section{Phylogenetic analysis}

The phylogenetic affiliation of $S c$. tatrae was elucidated based on molecular analysis of three nuclear (18S rDNA, ITS1 rDNA, ITS2 rDNA) and one plastid marker $(r b c \mathrm{~L})$. The $18 \mathrm{~S}$ rDNA gene sequence of Sc. tatrae was identical with $\mathrm{Cr}$. nivalis from the Austrian Alps (sample P24/DR4, accession number GU117576.1, Remiss et al. 2010) except for two ambiguous bases at the end of the P24/DR4 sequence resulting in identity 99.9\% (identical 1697 from 1699 bases). This affiliation was supported by comparing the secondary structures of the ITS2 region between the Slovak and the Austrian populations (letters outside the structure indicate differences; Fig. 28): Twenty nucleotide differences were found, one in the helices I and II, both of them were located in single stranded regions, ten differences in the most conserved helix III and eight changes in expansion segments between the III. helix and LSU stem. There was no compensatory base change (CBC; changes on both sides of structures which maintain the pairing between nucleotides). One hemi-CBC ( $\mathrm{hCBC}$; change only on one side maintaining the pairing) was found in helix III (A-U in Cr. nivalis vs. A-G in Sc. tatrae, marked by asterisk in Fig. 28). ITS2 rDNA identity was $94.5 \%$ (identical 342 out of $362 \mathrm{bp}$ ). A close affiliation between both taxa was deduced also from a pairwise comparison of the variable nuclear marker ITS1 rDNA, revealing 98.4\% identity (identical 308 of $313 \mathrm{bp}$; three substitution detected and two ambiguous bases in the P24/DR4 sequence). There was no other more similar ITS2 sequence in public databases which can be used for secondary structure comparison with Sc. tatrae since other hits in BLAST search showed identity less than $76 \%$ and query cover less than $57 \%$. The plastid marker $(r b c \mathrm{~L})$ of $S c$. tatrae was $99.6 \%$ identical with the corresponding of Cr. nivalis P24/ 

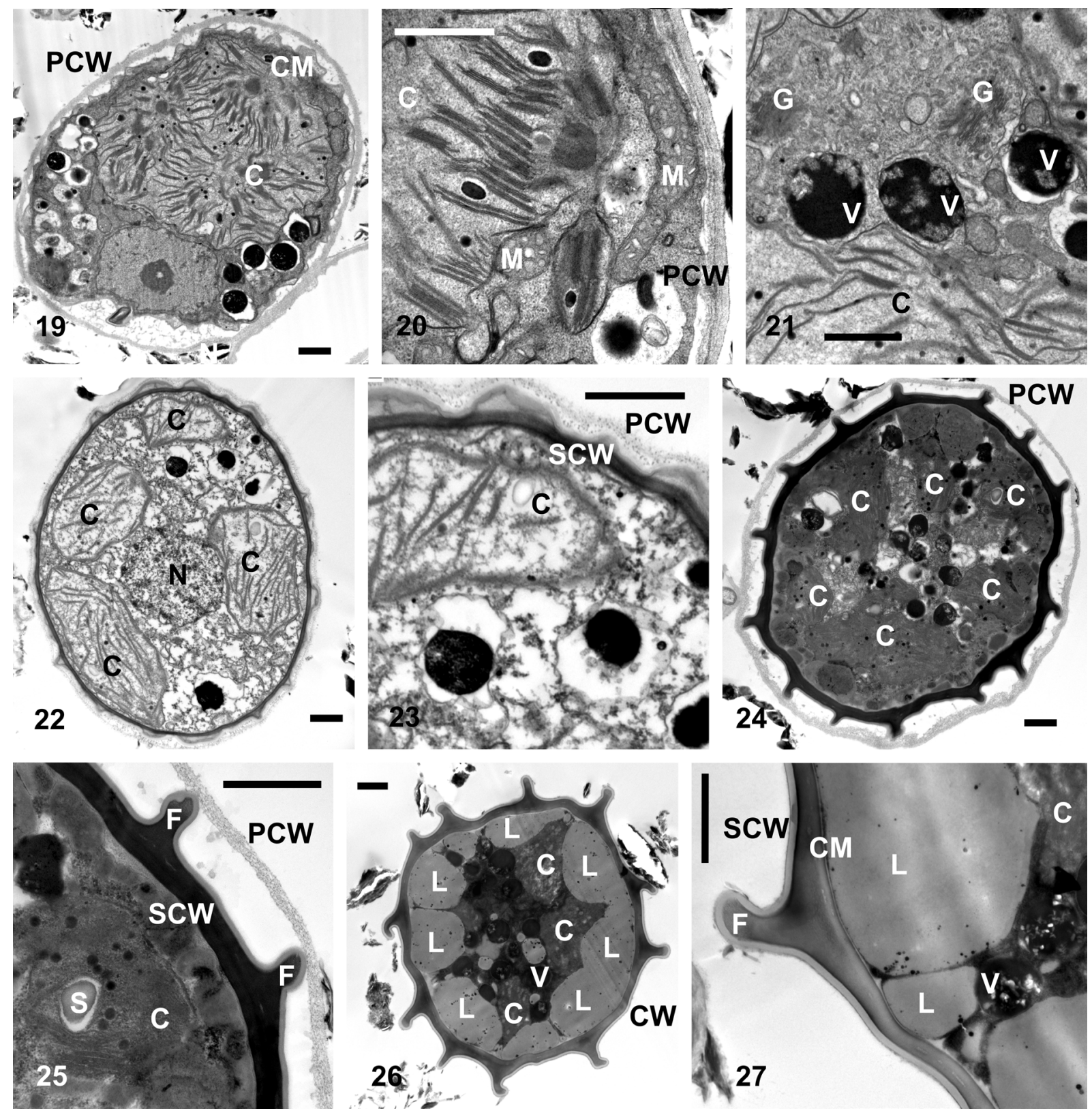

Figs 19-27. TEM micrographs of Chloromonas nivalis subsp. tatrae subsp. nov.: (19-21) young ovoid aplanozygotes, (19) young cyst with nucleus (N) smooth primary cell wall (PCW) one compact chloroplast (C) and an undulated cell membrane (CM), (20) detail of a young cyst, additionally showing mitochondria (M), (21) detail of the cytoplasm showing numerous ribosomes and Golgi stacks (G), indicating high metabolic activity, and vacuoles (V) occupied by electron dense, partly crystalline material; (22-25) intermediate aplanozygotes, (22) several smaller peripheral chloroplasts $(\mathrm{C})$ and the nucleus $(\mathrm{N}),(23)$ a detail showing a chloroplast $(\mathrm{C})$, the primary $(\mathrm{PCW})$ and the secondary cell wall (SCW), (24) flanges at the secondary cell wall surface surrounded by the primary cell wall (PCW), (25) detail of the primary cell wall (PCW) and the bi-layered secondary cell wall (SCW) with surface flanges (F), peripheral chloroplasts (C) including starch grain (S); (26-27) mature aplanozygotes, (26) fully developed flanges, cytoplasm occupied by large peripheral lipid bodies (L), whereas electron dense vacuoles (V) and chloroplasts (C) are centrally located, (27) detail of the bilayered secondary cell wall (SCW), cell membrane (CM), fully developed flange (F), chloroplast (C) and crystalline content of electron dense vacuoles (V). Scale bars $1 \mu \mathrm{m}$.

DR4 (560 out of $562 \mathrm{bp}$, two ambiguous bases in P24/ DR4 sequence were present in one codon, thus one amino acid in the product of translation was labelled as ' $\mathrm{X}$ ', sequenced in this study) and showed a sister relationship to $\mathrm{Cr}$. sp. 'Gassan $\mathrm{B}$ ' from Japan (identity $96.5 \%$, identical 1004 out of 1039 bp, sequence LC012743.1, see the phylogenetic tree - Fig. S14 in MatsuZaKi et al. 2015).

\section{Photosynthesis}

In order to test the photosynthetic activity of this snow alga, the performance of field samples was measured under different light levels at the temperature of the melting snow habitat (photosynthesis/irradiance-curves). In general, aplanozygotes of Sc. tatrae were physiologically active and exhibited an $\alpha$ value of $0.19 \pm 0.01$, a relative $\mathrm{ETR}_{\max }$ of $21.8 \pm 1.0$ and an 


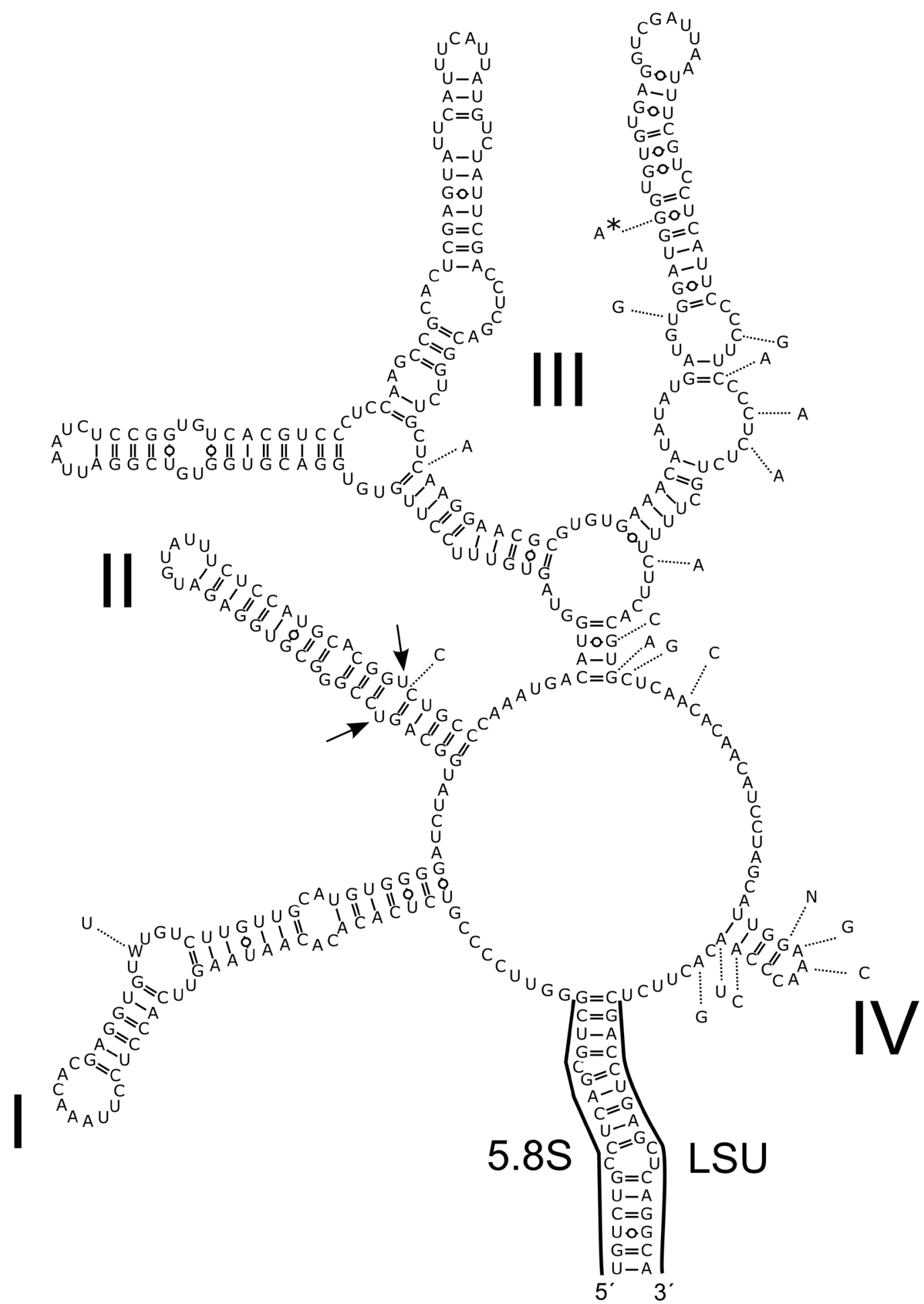

Fig. 28. Comparison of secondary structure of ITS2 rDNA transcripts between Chloromonas nivalis subsp. tatrae (accession number: KY499614, this study) and Chloromonas nivalis from the Austrian Alps (accession number GU117576.1, RemIAS et al. 2010). Note the U-U mismatch in the helix II (arrowheads). Differences characteristic for the latter are shown by nucleotides outside of the structure. The asterisk indicates hemi-compensatory base change.

$\mathrm{I}_{\mathrm{k}}$ value of $149 \pm 18 \mu$ mol.photons.m $\mathrm{m}^{-2} \cdot \mathrm{s}^{-1}$ (Fig. 29). Photoinhibition was noticed from $600 \mu \mathrm{mol} \cdot \mathrm{m}^{-2} \cdot \mathrm{s}^{-1}$ on. For comparison, values of $\mathrm{Cr}$. nivalis from the Austrian Alps (from Remias et al. 2010) were integrated in Fig. 29 and showed a likewise photosynthetic performance. The only difference was a lower parameter $I_{k}$ about one third for Cr. nivalis $\left(\mathrm{I}_{\mathrm{k}}=106 \mu\right.$ mol.photons $\left.\mathrm{m}^{-2} \cdot \mathrm{s}^{-1}\right)$. The irradiance level from which on Cr. nivalis was subject to photoinhibition is not known, because application of higher irradiance levels in Remias et al. (2010) were not possible due to technical reasons. 
Table 4. Statistical significance in differences of aplanozygotes length, width and length to width ratio (L:W) between Cr. nivalis subsp. tatrae from the High Tatra Mts. and Cr. nivalis from the Austrian Alps, and among latter group; ns - not significant.

\begin{tabular}{lll}
\hline & $\begin{array}{l}\text { Cr. nivalis subsp. tatrae } \\
\text { vs. } \text { Cr. nivalis }\end{array}$ & among Cr. nivalis \\
\hline Length & $<0.0001$ & \\
Width & $<0.05$ & $<0.005$ \\
L:W ra- & $<0.0001$ & $<0.05$ \\
tio & & n.s. \\
\hline
\end{tabular}

\section{Pigments}

In mature aplanozygotes, chlorophyll-a and - b accounted for $46.6 \%$, primary (plastidal) carotenoids $12.0 \%$ and secondary (non-plastidal) carotenoids $41.4 \%$. The latter were identified as derivatives of the keto-carotenoid astaxanthin by their spectral absorbance and occurred as 3 peaks. Their late retention times the nonpolar region (compared to non-derivative astaxanthin standard) of the chromatogram point to the presence of astaxanthin esterified with a variety of different FAs. The ratio astaxanthin to chlorophyll- $a$ was 1.465 . Other secondary carotenoids were not detected.

\section{Fatty acid composition}

The relative content of FAs (as \% of total lipids and as $\%$ in the three major lipid groups) in Sc. tatrae is given in Table 5. FAs with 14 to 18 carbon atoms were detected. The cells had a high level of PUFAs (49\% in total lipids), whereas the content of saturated acids did not exceed $34 \%$ (formed mainly by palmitic acid, 16:0). The main monounsaturated fatty acid (MUFA) was oleic acid $(18: \ln 9,14 \%)$. The major PUFA were $\alpha-$ linolenic acid $(18: 3 \mathrm{n} 3,19 \%)$, followed by linoleic acid (18:2n6, $10 \%)$, hexadecatetraenoic acid (16:4n3, $7 \%)$ and steariadonic acid $(18: 4 \mathrm{n} 3,6 \%)$. There were significant differences in FA composition among the three major lipid classes. The level of saturated lipids was the highest in neutral lipids (48 \%), whereas PUFAs were dominant in phospholipids $(67.1 \%)$ and glycolipids (69\%) (Table 5). The total lipid content in the biomass was $17.6 \%$ (of dry weight).

\section{Taxonomic treatment}

Chloromonas nivalis subsp. tatrae (KOL) ProcházKová, Remias, ŘezanKa et Nedbalová subsp. nov. Synonym: Scotiella tatrae KoL 1965: 147, figs 1-5, 8-11. Basionym: Pteromonas nivalis CHODAT 1902: 145, fig. 70.

Description: mature zygote (causing the coloured snow phenomenon) elongate to somewhat fusiform, 16.4-24.0 $\mu \mathrm{m}$ long, 10.0-16.2 $\mu \mathrm{m}$ wide, length to width ratio $1.55-1.64$, one nucleus, single axial chloroplast or several smaller spherical ones, abundant peripheral lipid globules containing orange carotenoids

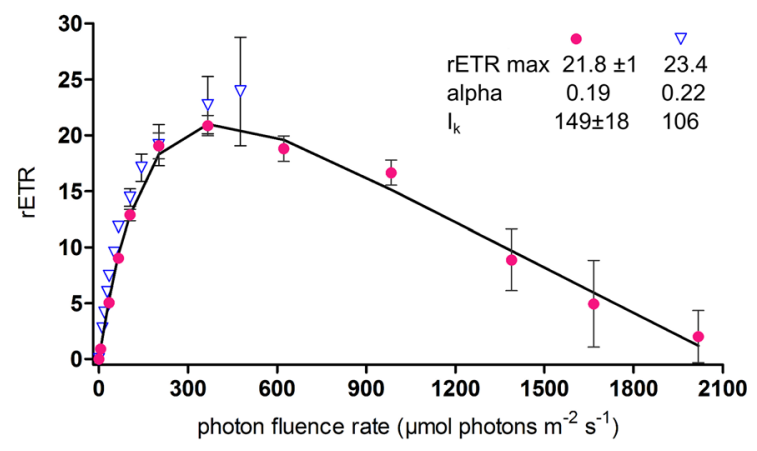

Fig. 29. Comparison of the light-dependent relative electron transfer rate (rETR) between the aplanozygotes of Chloromonas nivalis subsp. tatrae (full circles, this study) and Chloromonas nivalis from the Austrian Alps (open triangles, REMIAS et al. 2010). Values of maximum relative electron transfer rate $\left(\mathrm{rETR}_{\max }\right)$, initial slope $(\alpha)$ and saturation irradiance $\left(I_{k}\right)$ for both species are shown. The data points were fitted with the model of photoinhibition according to WALSBY (1997). Each symbol represents the mean value of four and three replicate measurements $( \pm \mathrm{SD})$ for the former and latter species, respectively.

(astaxanthin to chlorophyll ratio $\sim 1.5$ ), two layered cell wall, most frequently 10-12 flanges, rarely less (9) or more (up to 14) in the equatorial region of the cell surface; aplanozygote division into four daughter cells, which are smooth-walled elongate 15.4-20.4 $\mu \mathrm{m}$ long, 4.5-6.7 $\mu \mathrm{m}$ wide; occurring in open sites above timberline; flagellates unknown; no pyrenoid or stigma visible; young zygote smooth-walled still without flanges, one compact chloroplast.

Holotype: specimen LP01 deposited at Herbarium of CAUP (Charles University in Prague), material consists of gold coated aplanozygotes.

Iconotype: Figs 5-27.

Etymology: The species epithet tatrae is based on the name of the geographic region, the Tatra Mountains, where it was found. It is genitive of the substantive 'Tatra' and this form corresponds with former description of 'Sc. tatrae' done by Kol.

Type locality: Snow fields close to the rocky shore of Capie Lake (Mlynická Valley), High Tatra Mountains, Poprad District, Slovakia.

Distribution: so far known from snowfields on shores of four alpine lakes: Okrúhle Lake, Capie Lake, Vyšné Kozie Lake (Mlynická Valley) and Upper Sesterske Lake (Velká Studená Valley) in the High Tatra Mountains, Slovakia.

Remarks: Any deposited material from the first observation of 'Sc. tatrae' is unknown. KoL (1965) reported 10-12 cell wall flanges on basis of LM. Cr. nivalis subsp. tatrae differs from $\mathrm{Cr}$. nivalis sensu CHODAT (1902) in having mostly 10 or more flanges on cross-section instead of 8-9. Besides, Cr. nivalis in the Austrian Alps (REMIAs et al. 2010) differs from subsp. tatrae physiologically in the accumulation of 
Table 5. Fatty acid composition (as \% of total lipids and three major lipid groups) of Chloromonas nivalis subsp. tatrae field sample (LP01). The table gives only those fatty acids that have abundances greater than $0.1 \%$. The relative proportion of saturated (SAFA), monounsaturated (MUFA) and polyunsaturated (PUFA) fatty acids is also given.

\begin{tabular}{lrrrr}
\hline Fatty acid & \% total lipids & \% neutral lipids & \% phospholipids & \% glycolipids \\
\hline $14: 0$ & 0.1 & 0.1 & 0.1 & 0.1 \\
$16: 0$ & 23.2 & 37.3 & 15.2 & 13.8 \\
$16: 1 n 9$ & 0.9 & 0.8 & 1.0 & 0.9 \\
$16: \ln 7$ & 1.2 & 1.5 & 1.3 & 1.1 \\
$16: 2 n 6$ & 1.4 & 1.5 & 1.8 & 1.7 \\
$16: 3 \mathrm{n} 4$ & 1.7 & 1.8 & 2.3 & 2.1 \\
$16: 3 \mathrm{n} 3$ & 1.4 & 1.1 & 1.5 & 1.7 \\
$16: 4 n 3$ & 6.7 & 3.2 & 7.6 & 8.5 \\
$17: \ln 8$ & 0.4 & 0.2 & 0.3 & 0.5 \\
$18: 0$ & 10.1 & 10.8 & 4.3 & 5.3 \\
$18: \ln 9$ & 14.1 & 18.1 & 9.8 & 8.5 \\
$18: \ln 7$ & 1.1 & 1.2 & 0.9 & 0.8 \\
$18: 2 \mathrm{n} 6$ & 10.3 & 6.4 & 15.2 & 12.5 \\
$18: 3 \mathrm{n} 6$ & 2.0 & 1.1 & 2.2 & 2.1 \\
$18: 3 \mathrm{n} 3$ & 19.3 & 12.8 & 26.7 & 28.7 \\
$18: 4 \mathrm{n} 3$ & 6.1 & 2.1 & 9.8 & 11.7 \\
SAFA & 33.4 & 48.2 & 19.6 & 19.2 \\
MUFA & 17.7 & 21.8 & 13.3 & 11.8 \\
PUFA & 48.9 & 30.0 & 67.1 & 69.0 \\
\hline
\end{tabular}

secondary carotenoids (about three times lower astaxanthin to chl-a ratio in mature cells for the former) and slightly larger cell sizes of aplanozygotes: $(18.4-27 \times$ 10.6-16 $\mu \mathrm{m})$. Aplanozygotes of Cr. nivalis from North America (Hoham et Mullet 1977) possess a lower number of flanges at cross-section (six to eight), are larger $\left(16-37 \times 10^{-27} \mu \mathrm{m}\right)$ and lack fusing/diverting flanges apart from the apex (the latter are typical for Cr. nivalis from the Austrian Alps and for Cr. nivalis subsp. tatrae).

\section{Discussion}

Scotiella tatrae was initially described from red and pink snow in the High Tatra Mountains at Okrúhle Lake, $2000 \mathrm{~m}$ a.s.l. (formerly Döller Lake) where it developed an almost monospecific bloom (KoL 1965). In a much lower extend, Cr. nivalis was also present, but no exact proportion to the former was given ('in einer kleineren Menge' according to KoL 1965). In that report, scattered cells of Chlamydomonas $(\mathrm{Cd}$.) nivalis (BAUER) WILle, fungi Chionaster nivalis and Chionaster bicornis Kol were found as well. We collected our sample from a snow field close to the shore of Capie Lake, which is situated about $150 \mathrm{~m}$ south from the place of the initial observation (Fig. 2). Generally, the subspecies tatrae seems to be restricted to the High Tatra Mountains and can thus be likely regarded as endemic. A single report of scattered cells from elsewhere (Kühtai region, $2500 \mathrm{~m}$ a. s. 1., Tyrolean Alps, Austria) by KoL (1970) should be questioned, because such observation of Sc. tatrae in Austrian Alps has never been repeated in spite of intensive cryobiological research of this region (Remias et al. 2010).

For the population harvested in course of this study, the new name combination Cr. nivalis subsp. tatrae is proposed, since it shows a very close molecular affiliation to Cr. nivalis from the Austrian Alps based on the investigated molecular markers (18S rDNA, ITS1 rDNA, ITS2 rDNA, $r b c \mathrm{~L}$ ). CBCs in ITS2 secondary structures correlate with Ernst Mayr's biological species concept (Coleman 2009). This hypothesis is also referred to as the $\mathrm{CBC}$ species concept. In our study, no CBCs in conserved parts (helices II and III) were detected, however, nucleotide difference in this 
variable marker between $C r$. nivalis subsp. tatrae and Cr. nivalis of about $5.5 \%$ suggests that a molecular divergence between them is ongoing. In comparison, it was nearly two fold higher than in two strains of $C d$. reinhardtii $\mathrm{P}$. A. DANGEARD, NIES-2463 and SAG 11-32a, which can cross and produce zygotes $(3.3 \%$, NAKADA et al. 2010). On the other hand, it was slightly less than that between Microglena basinucleata Demchenko, Mikhailyuk \& Pröschold and M. monadina (EHRENBERG) STEIN (5.9\%), recently separated taxa based on polyphasic approach including several CBCs in helix III (Demachenko et al. 2012). On the other hand, even in absence of any CBC, algae may belong to the different species with a probability of 0.24 (WoLF et al. 2013) because total loss of gamete compatibility may be observed sooner than any CBC appear in the most conserved region of helix III (COLEMAN 2009). Between Cr. nivalis and subsp. tatrae, there were found similarities in the intracellular organization of aplanozygotes, cell sizes, photosynthetic performance and type of preferred habitat (see REMIAs et al. 2010). However, the significant differences in cell wall surface organization, a feature of taxonomic relevance, that seems to be stable considering no detectable changes since first descriptions of this snow alga several decades ago, justified the setup of a new subspecies. It remains open, if hybrids between subsp. tatrae and the main form of Cr. nivalis occur.

\section{Ecology}

Low electrical conductivities and slightly acidic $\mathrm{pH}$ were characteristic for the habitat of Cr. nivalis subsp. tatrae (Table 3). These findings are in good agreement with environmental conditions recorded for Cr. nivalis in the Austrian Alps $(\mathrm{pH}=4-6.2, \mathrm{EC}=$ 2.8-7.2 $\mu \mathrm{S} . \mathrm{m}^{-2} . \mathrm{s}^{-1}$; Remias et al. 2010). $\mathrm{pH}$ values of snow meltwater with algae present were summarised in Нонам et al. (2007). They ranged from 3.8 to 8.1, with Cr. pichinchae WILlE in the most acidic environment close to coniferous trees (Нонам 1975) and $C r$. polyptera (Fritsch) HoHAM, Mullet \& ROEMER in the most alkaline meltwater influenced by a guano input from close penguin colonies (Ling \& SEPPELT 1998). Similarly high $\mathrm{pH}$ of meltwater (7.7-7.9) was caused by input of volcanic ash (LuTz et al. 2015). Meltwater conductivities with snow algae present varied from $<1$ to $950 \mu \mathrm{S} \cdot \mathrm{m}^{-2} \cdot \mathrm{s}^{-1}$. For instance, the very low values were found in arctic habitats of red orange cells affiliated to clade of $C d$. nivalis $(\mathrm{EC}=0.83)$ and $C r$. nivalis $(\mathrm{EC}=7.4)$ in Svalbard (MüLLER et al. 1998). High EC was reported from the environment of $\mathrm{Cr}$. polyptera in Antarctica in close proximity to bird colonies (LING \& SEPPELT 1998). The snow water contents in snow surface samples containing $C r$. nivalis subsp. tatrae are in good agreement with $C r$. nivalis (45-52 \%; НоHAM \& Mullet 1977). This parameter is influenced by air temperatures during day and depends also to the depth of sampling (HoHam \& Mullet 1977). Generally, the availability of liquid water in the snow influences the life cycle development of Chloromonas snow algae: sexual stages occur if SWC is lower (47-54\%), whereas the asexual phase dominate during a higher SWC values (57-63\%, HoHAm \& Duval 2001). The population density of Cr. nivalis subsp. tatrae was twice times higher than the detection limit from which on snow discolouration can be recognized by bare eyes $\left(>10^{4}\right.$ cells per $\mathrm{ml}^{-1}$ of meltwater; HoHAM \& Duval 2001). Generally, the intensity of colouration may change in dependence on the cellular pigment composition, prevailing life cycle stage and the seasonality. Due to melt water flush out processes, cryoflora can have an important impact on biota feeding on algae in adjacent lakes. The period of serious acidification of the High Tatra lakes in the $20^{\text {th }}$ century was accompanied with a decrease of phytoplankton biomass to nearly zero values. The inflow of cryoflora (probably mainly $\mathrm{Cr}$. nivalis subsp. tatrae) into Okrúhle Lake was thus believed to be the key food supply for planktonic calanoid copepod Arctodiapomus alpinus IMHOF that enabled its survival despite of the acidification-induced processes of oligotrofication (HořICKÁ et al. 2006).

\section{Morphology and ultrastructure}

The aplanozygote sizes of 'rediscovered' populations of Sc. tatrae $(16.4-24 \times 10-16.2 \mu \mathrm{m})$ fit to the original description $(18-24 \times 12-15 \mu \mathrm{m} ; \mathrm{KoL} 1965)$. The morphological similarity of 'Sc. tatrae' and Cr. nivalis (formerly Sc. nivalis) was confirmed earlier by a cluster analysis where all species with Scotiella-like morphology were included (Комáromy 1982). The striking difference is a morphologic variation: most commonly 10 to 12 flanges per cell in cross-section typical are a constant feature for $\mathrm{Cr}$. nivalis subsp. tatrae. On the contrary, Cr. nivalis aplanozygotes from the Austrian Alps have usually 8 to 9 flanges only (Remias et al. 2010). In both taxa, the organization of flanges is consistent, except for the rare case of two flanges reaching from opposite cell poles and finally touching at the equatorial region of the cell (Fig. 16), which has not been observed in $\mathrm{Cr}$ nivalis from Alps. The aplanozygote sizes of the new subspecies were slightly smaller than those of the relative from the Alps. However, a large variability of aplanozygote lengths among samples of Cr. nivalis (Fig. S1, Table 4) is probably reflecting individual growth conditions depending on the date of sampling in course of the season, and furthermore the abiotic microhabitat and weather conditions before sampling. The known life cycle of $\mathrm{Cr}$. nivalis comprises vegetative flagellates which cleave into two, four, eight or sixteen daughter cells. Daughter cells behave as zoospores or gametes. Generative fusion of two gametes leads to development of a quadriflagellate motile zygote. After a while, loss of flagella takes place (transformation to an aplanozygote), the primary cell wall is shed and exposing the developing secondary wall structures of the zygote (HoHAm \& Mullet 
1977). For Cr. nivalis for the Alps, swarmers with four flagella were many times found in the field, another indication of sexual reproduction is the empty shed cell wall directly after the putative fusion (REMIAs et al. 2010). As subsp. tatrae is closely related to the main form, asumption was made that observed cells were aplanozygotes indeed. This concept is supported by the observation of a fading primary cell wall in this study, surrounding young aplanozygotes (' $\mathrm{PCW}$ ' in Figs 19-20). The secondary aplanozygote cell wall is formed below ('SCW' in Figs 22-25) and later made of two distinguishable layers, whereat the inner layer is more electron-dense (Figs 26-27). Differently to our own field observations, LING \& SEPPELt (1998) and Нонам et al. (2002) reported that two snow algal species from the genus Chloromonas can form cysts directly from vegetative flagellates without sexual fusion (vegetative hypnoblasts). Cr. nivalis subsp. tatrae zygotes started to cleave in original meltwater approximately 100 days after sampling and developed four elongate daughter cells. Timing of cleavage and daughter cell shapes were consistent with observation for $\mathrm{Cr}$. nivalis from the North America. Cell sizes were about one third larger for the latter one $(6-10 \mu \mathrm{m} \times 19-28$ $\mu \mathrm{m}$ in Hoham \& Mullet (1977).

Cytosolic, electron dense vacuoles, commonly filled with striking crystalline structures at the TEM level (Fig. 21), play a role in intracellular polyphosphate and polyamine storage (ОтA et al. 2016). Despite their abundant presence, they have been frequently neglected for microalgae. Cr. nivalis subsp. tatrae possesses these membrane-bound depots, like many other snow algae (REmias 2012). Accordingly, ubiquitous lipid bodies play a significant role to overcome demanding situations in the beginning of the seasonal life cycle (e. $\mathrm{g}$. as storage of energy for flagellate migration towards snow surface in spring). Their localization at the cell periphery, together with the accompanying accumulation of astaxanthin, provides a protection of centrally located organelles like chloroplast and nucleus against harmful UV or excessive visible irradiation. The reorganization of a single chloroplast of vegetative cells (Fig. 19 - note thylakoids arranged in distinct clusters, a putative preparation for plastid rearrangement) into several smaller sections during aplanozygote maturation (Figs 22, 26) has been observed at all known species of Chloromonas from snow (REMIAs et al. 2010). Several plastids types may be present in a single species during its life cycle, such as occur in Cr. chenangoensis Hoham, Berman, Rogers, Felio, Ryba et Miller and Cr. tughillensis Hoham, Berman, Rogers, Felio, RyBa et Miller from snow (HoHAm et al. 2006). Thus, paying attention only to vegetative stages of chlamydomonads kept in laboratory cultures can lead to partly misleading conclusions in case much emphasis is placed on chloroplast morphology (MATSUZAKI et al. 2014, 2015), but the change of plastid shapes during life cycle is not considered. Physiological adaptation of observed intracellular reorganisation may be following: this raise in plastid membrane surface to volume ratio provides probably advantages due to better metabolite exchange for survival in drastically changing cold habitats at the end of growing season. Also the development secondary cell wall flanges during aplanozygote maturation can be generally regarded as a mechanism of mechanical protection, which becomes effective after complete snowmelt and cells are subject to draught when exposed at bare rock surfaces (REMIAs 2012).

\section{Other genetically and morphologically related snow algal species}

Zygotes of $\mathrm{Cr}$. cf. nivalis have been recorded from all continents except Australia (KoL 1968; Duval et al. 1999). However, according to $18 \mathrm{~S}$ rDNA and $r b c \mathrm{~L}$ phylogeny, $C r$. nivalis-like aplanozygotes were found in at least four independent lineages, and each lineage is located in a different geographic region (Japan, Svalbard, North America and Europe; see the phylogenetic tree in Fig. S13 in MatsuZaKi et al. 2015), suggesting a geographical barrier of dispersion or isolation. Another explanation could be an independent snow colonization several times in the evolution history of ' Cr. cf. nivalis'.

Zygotes of the snow alga Cr. pichinchae from the North America were reported to resemble 'Sc. tatrae' in number of flanges per cell [(6)9-11(15)] and cell size (17-20 × 11-14 $\mu \mathrm{m})$ (Нонам 1975). Accordingly, HoHAM \& Mullet (1978) suggested in their taxonomic notice that 'Sc. tatrae' is a zygotic stage of Cr. pichinchae. However, strain Cr. pichinchae UTEX SNO 33 is well separated from the Cr. nivalis from the Austrian Alps according to $18 \mathrm{~S}$ phylogeny (see Fig. S13 in MATSUZAKI et al. 2015). Independent evolution can be inferred also from ecology, because $C r$. pichinchae prefers shaded habitat under heavy forest canopy (НоHAM 1975) whereas Cr. nivalis subsp. tatrae causes blooms at exposed sites above timberline. Cr. hohamii LING \& SEPPELT is another morphologically related snow algae, however with a higher numbers of usually undulating flanges per cell [12-16(20)] (HoHAM et al. 1983; LING \& Seppelt 1998). Additionally, it has, like in the case of $\mathrm{Cr}$. pichinchae, a different molecular affiliation than Cr. nivalis subsp. tatrae. The $18 \mathrm{~S}$ rDNA sequence of Cr. hohamii UTEX SNO 67 represents an independent lineage (see Fig. S13 in MATSUZAKI et al. 2015) which is also supported by a different geographical distribution (Hoham et al. 1983, Ling \& Seppelt 1998). The sister lineage to $\mathrm{Cr}$. nivalis from the Austrian Alps (and thus to Cr. nivalis subsp. tatrae) is represented by Cr. polyptera (based on $18 \mathrm{~S}$ phylogeny in MATSUZAKI et al. 2015), a snow algae described from Maritime Antarctica (FrITSCH 1912). The putative vegetative hypnoblasts of this species occur in coastal, penguininfluenced places and differ morphologically in possessing a very high number of flanges (18-23 per cell; AKIYAMa 1979), in preference of neutral to alkaline $\mathrm{pH}$ 
(6.7-8.1; LING \& SEPPELT 1998) and in elevated supply of nutrients from bird colonies (electrical conductivity $56-950 \mu \mathrm{S} . \mathrm{cm}^{-1}$ in LING \& SEPPELT 1998; 42-95 $\mu \mathrm{S} . \mathrm{cm}^{-1}$ in Remias et al. 2013). Contrary, habitat conditions $C r$. nivalis subsp. tatrae are characterised by low conductivities and slightly acidic $\mathrm{pH}$ (Table 3 ).

Recent approaches use effective high-throughput sequencing protocols to elucidate OTUs (operational taxonomic units) and their abundances in whole cryoflora communities, thus describing the biodiversity of snow microbiomes (LuTz et al. 2016). Apparently, the use of a single gene for eukaryotes, especially when only sections of the conservative $18 \mathrm{~S}$ rDNA are available by this method in the context of Chlorophyta, does not provide sufficient resolution to reflect the actual taxonomic richness. Cr. nivalis subsp. tatrae is an example that a "rare" or regionally distributed taxon could be overseen depending on the used gene, because clear morphologic differences to the standard form of $\mathrm{Cr}$. $\mathrm{ni}$ valis cannot be evaluated by using $18 \mathrm{~S}$ rDNA.

\section{Pigment composition}

The survival of microalgae at exposed, nutrient-poor snow surfaces frequently goes along with the accumulation of secondary carotenoids (REMIAs 2012). One the one hand, these pigments effectively absorb excessive visible and near ultraviolet irradiation, thus protecting the photosystems against photoinhibition (BIDIGARE et al. 1993). On the other hand, carotenoids are nitrogenfree compounds which can be abundantly synthesized also in nitrogen-poor habitats. So far, Chlorophycean snow algae have been reported to accumulate exclusively astaxanthin and derivatives, which are stored in cytoplasmic lipid globules (REMIAs et al. 2016). It is the same with $\mathrm{Cr}$. nivalis subsp. tatrae, which's pigments have, to our knowledge, been analysed for the first time. Generally, the cellular amount of astaxanthin in microalgae is illustrated as a relative ratio to chlorophyll (BIDIGARE et al. 1993; REMIAS \& LÜTZ 2007). This ratio reflects either the level of aplanozygotes maturity during life cycle (the higher ratio, the older the cells; REMIAS et al. 2010), or in a tentative chemotaxomical approach, it shows a distinct range of ratios found for certain clades or taxa. For example, the astaxanthin to chlorophyll ratio was three times higher for mature aplanozygotes of $C r$. nivalis subsp. tatrae than that of comparable cells of $\mathrm{Cr}$. nivalis from the Austrian Alps (REMIAs et al. 2010). This suggests a higher tolerance to excessive irradiation for the former population, but still five times lower values in comparison with dark red cells of the common snow alga $C d$. nivalis, which is usually found at the most exposed high alpine and polar sites (REMIAs et al. 2005). The relative proportions of pigment classes in aplanozygotes of $\mathrm{Cr}$. nivalis subsp. tatrae and Cr. nivalis (REMIAs et al. 2013) slightly differ, containing twice as many secondary carotenoids, but one third less primary carotenoids and one quarter less chlorophylls for the former alga. In both cases, astaxanthin was the only secondary carotenoid. Accordingly, the cellular astaxanthin content reflects the specific snow coloration such as brownish-red for subsp. tatrae or blood- to crimson red snow for $C d$. nivalis (REMIAs et al. 2005).

\section{Photosynthesis}

The adaptation of Cr. nivalis subsp. tatrae to rather high irradiation conditions can be deduced not only from abundant levels of astaxanthin, but also from its photosynthetic performance, such as high light saturation point $\left(I_{k}=149\right)$, light saturation rate $\left(E_{\text {TR }}=21.8\right)$ and the irradiance level from which on, photoinhibition takes place $\left(600 \mu \mathrm{mol}\right.$ photons $\left.\mathrm{m}^{-2} \cdot \mathrm{s}^{-1}\right)$. Moreover, photosynthesis showed positive rETR values even at irradiance levels $\left(<2100 \mu\right.$ mol.photons. $\left.\mathrm{m}^{2} . \mathrm{s}^{-1}\right)$ close to full sunlight (up to $2500 \mu \mathrm{mol} . \mathrm{m}^{-2} \cdot \mathrm{s}^{-1}$ at Ladové Lake with an elevation of $2057 \mathrm{~m}$, the High Tatra Mountains; unpublished results from the automatic meteorological station). Cells may be subject to such irradiances and have to cope with photoinhibition when they are accumulated on snow surface due to proceeding snow melt. Additionally, this species is also able to perform well under low light conditions: Since penetration of irradiation decreases logarithmically with depth of snow column (GorTon \& Vogelman 2003), a high alpha value of 0.19 supports cells located a few centimetres below the snow surface to perform positively. In comparison, mature aplanozygotes of $\mathrm{Cr}$. nivalis from the Austrian Alps seems to be saturated by light at slightly lower irradiance levels $\left(\mathrm{I}_{\mathrm{k}}=106\right)$ what is probably related to their lower astaxanthin content. Flagellate stages of Cr. nivalis are lacking secondary pigments (НонАм \& Mullet 1977). One of their protective mechanisms against high irradiance is believed to be the active migration to deeper parts of the snow pack (KvíDEROví 2010). Diurnal decrease of rETR and alpha value during noon and successful recovery a few hours later in response to irradiance at open sites was documented for vegetative flagellates tentatively designed as $\mathrm{Cr}$. cf. nivalis (KvíDEROvá 2010). The preference of low irradiances (about $100 \mu$ mol.photons. $\mathrm{m}^{-2} . \mathrm{s}^{-1}$ ) for flagellate stages of $\mathrm{Cr}$. nivalis originating from shady sites was demonstrated (STIBAL 2003). Similar irradiance levels below tree canopy were found in the upper $5 \mathrm{~cm}$ of snowpacks containing populations of $\mathrm{Cr}$. hohamii and Cr. nivalis in the North America (Нонам et al. 1998) and were proven to be optimal for mating of Cr. tughillensis and Cr. chenangoensis at lab conditions (НоHAM et al. 2006). In our study, we have shown physiological borders for photosynthesis of aplanozygotes of $\mathrm{Cr}$. $\mathrm{ni}$ valis subsp. tatrae, whereas growing optima of vegetative stages remain unknown due to a lack of cultures.

\section{Fatty acid composition}

The desaturation of FAs in biomembranes is considered as one of the main mechanisms of adaptation and acclimation of photosynthetic microorganism to cold 
environments (MoRGAN-KISS et al. 2006). The number and position of double bonds together with FA chain length markedly influence melting point (MP) of FA and thus fluidity, permeability and stability of biological membranes (e.g. $\mathrm{MP}=-11.58^{\circ} \mathrm{C}$ for $\alpha$-linolenic acid; $\mathrm{MP}=65.45^{\circ} \mathrm{C}$ for palmitic acid, $16: 0$; KNOTHE \& DUNN 2009). For example, the levels of oleic acid (18:1n9) and $\alpha$-linolenic acid (18:3n3) decreased in thylakoid membranes upon increase of exposure temperatures from low to mesophilic (LUKEŠ et al. 2014). The $\alpha$-linolenic acid as the dominant unsaturated FA in cells of $\mathrm{Cr}$. $n i$ valis subsp. tatrae (19.3\% in total lipids) is consistent with profiles of other Chloromonas species harvested from snow ( $C r$. pichinchae, 22.9-25.7\%; Řezanka et al. 2014) or of a strain kept in nitrogen deficient medium (Cr. nivalis CCCryo 005-99, 35\%; SPIJKERMAN et al. 2012). A high contribution of this FA seems to be typical for all 22 Chloromonas species screened in the study of LANG et al. (2011) (average $27 \%$ ). On the contrary, snow algae from a different clade related to $C d$. nivalis, show a dominance of oleic acid ( 59\%: BIDIGARE 1993; 45\%: SPIJKERMAN etal. 2012), suggesting that phylogenetic aspects can play a role in native FA patterns within the Chlamydomonadales. This study showed that FAs containing C16 and C18 chains with 0 to 4 double bonds were dominating in aplanozygotes of $C r$. nivalis subsp. tatrae. A different profile with dominating medium to long chain FAs of C11 to $\mathrm{C} 18$ chains with 0 to 5 double bonds were found in snow dwelling flagellates of Cr. brevispina (FRITSCH) Hoham, Roemer \& Mullet ( ̌rezanka et al. 2008). The high level of PUFAs of $\mathrm{Cr}$ nivalis subsp. tatrae (48\%) is comparable with field samples of other Chloromonas species from snow (Cr. brevispina, 74\%, Rezanka et al. 2008; Cr. pichinchae, 59-70\%, Rezanka et al. 2014) and reflects a suitable strategy for life at temperatures close freezing point (KvíDEROVÁ 2010). The proportion of PUFAs in Cr. nivalis subsp. tatrae was nearly $70 \%$ in lipid groups associated with membranes, and it was twice lower in neutral lipids which are likely deposited in cytosolic lipid bodies as storage products (THOMPSON 1996). Generally, this is in agreement with data published on other microalgae, where PUFA content of the glycolipid and phospholipid fractions was higher than that of the neutral lipid fraction (e.g. HENDERSON et al. 1998). However, this pattern is extremely pronounced in Cr. nivalis subsp. tatrae suggesting that the high accumulation of PUFAs in membranes is important for its survival in the harsh snow environment.

\section{Conchusion}

In summary, $C r$. nivalis subsp. tatrae can be presumably regarded as an endemic variation of a common cryoflora species. It has been found so far only in the High Tatra Mountains (Slovakia). According to the analysis of several molecular markers, it is closely related to Cr. nivalis from the Austrian Alps. Despite having similar physiological performance and ecological requirements, they differ in the abundance of secondary carotenoids and certain morphological traits. Aplanozygotes (Cr. hohamii and $\mathrm{Cr}$. pichinchae) and putative vegetative hypnoblasts (Cr. polyptera) of further morphologically similar species living in snow can be distinguished by different habitat ecology, molecular traits and morphological details like number of flanges. High levels of polyunsaturated fatty acids were detected especially in membrane lipids. The taxonomic affiliation of $\mathrm{Cr}$. cf. nivalis-like species inhabiting further localities in the High Tatra Mountains listed in (KoL 1975a, b) and LUKAVSKÝ (1994) is still unclear. A phylogenetic position of other Scotiella species associated with snow (e.g. Sc. norvegica KoL) is lacking. To our experience, establishing cultures from aplanozygotes remains difficult. A polyphasic approach including molecular analysis of multiple DNA regions, description of ecology, cytology and physiology might help to reveal species identity of snow algae and evaluate biodiversity of polar and alpine regions.

\section{ACKNOWLEDGEMENTS}

This work was supported by Czech Science Foundation (GACR) project 17-00027S. We are grateful to Tomáš Hájek (University of South Bohemia in České Budějovice, Czech Republic) for technical assistance and Siegfried Aigner (University of Innsbruck, Institute of Botany, Austria) for assistance with HPLC analysis. We thank an anonymous reviewer for constructive comments.

\section{REFERENCES}

Aкiyama, M. (1979): Some ecological and taxonomic observations on the colored snow algae found in Rumpa and Skarvsnes, Antarctica. - Mem. Natl. Inst. Polar. Res. Spec. Issue 11: 27-34.

Bidigare, R.R.; ONDrUSEK, M.E.; ItURRIAGA, R.; HARVeY, H.R.; Нонам, R.W. \& MACкO, S.A. (1993): Evidence for a photoprotective function for secondary carotenoids of snow algae. - J. Phycol. 29: 427-434.

Bischoff, H.W. \& Bold, H.C. (1963): Phycological studies. IV. Some soil algae from Enchanted Rock and related algal species. - University of Texas, Publications 6318: 1-95.

Bligh, E.G. \& Dyer, W.J. (1959): A rapid method of total lipid extraction and purification. - Can. J. Biochem. Physiol. 37: 911-917.

BuchHolz, J. (1793): Beschreibung des wundervollen Karpatischen Schnee-Gebirges. - Ung. Mag. Pressburg, 3-47.

Chodat, R.(1902):Algues vertes de la Suisse. Pleurococcoïdes - Chroolépoïdes. Beiträge Kryptogamenflora der Schweiz. Band I, Heft 3. - pp. 1-373. Berne: Druck und Verlag von K-J. Wyss, Libraire-Éditeur.

Coleman, A.W. (2007): Pan-eukaryote ITS2 homologies revealed by RNA secondary structure. - Nucleic Acids Res. 35: 3322-3329.

Coleman, A. (2009): Is there a molecular key to the level of 'biological species' in eukaryotes? A DNA guide. 
- Mol. Phylogenet. Evol. 50: 197-203.

Cvetkovska, M.; Hüner, N.P.M. \& Sмith, D.R. (2016): Chilling out: the evolution and diversification of psychrophilic algae with a focus on Chlamydomonadales. - Polar Biol., doi:10.1007/s00300-016-2045-4.

Demachenko,E.;Mikhailyuk,T.;Coleman,A.\&Pröschold, T. (2012): Generic and species concepts in Microglena (previously the Chlamydomonas monadina group) revised using an integrate approach. - Eur. J. Phycol., 47: 264-290.

Dembitsky, V.M.; ŘRzanka, T.; Bychek, I.A. \& Shustov, M.V. (1991): Identification of fatty-acids from Cladonia lichens. - Phytochemistry 30: 4015-4018.

De Maayer, P.; Anderson, D.; Cary, C. \& Cowan, D.A (2014): Some like it cold: understanding the survival strategies of psychrophiles. - EMBO Rep. 15: 508-517.

Duval, B.; Duval, E. \& Hoham, R.W. (1999): Snow algae of the Sierra Nevada, Spain, and High Atlas mountains of Marocco. - Internatl. Microbiol. 2: 39-42.

EtTL, H. \& GärTner, G. (2014): Syllabus der Boden-, Luft- und Flechtenalgen.- 773 pp., Springer, Berlin, Heidelberg.

FritsCh, F.E. (1912): Freshwater algae collected in the South Orkneys by Mr. R. N. Rudmose Brown, B.Sc. of the Scottish National Antarctic Expedition, 1902-04. J. Linn. Soc. London Botany 40: 293-338.

Genty, B.; Briantais, J.-M. \& Baker, N.R. (1989): The relationship between the quantum yield of photosynthetic electron transport and quenching of chlorophyll fluorescence. - Biochim. Biophys. Acta (BBA) - General Subjects 990: 87-92.

Goff, L.J. \& Moon, D.A. (1993): PCR amplification of nuclear and plastid genes from algal herbarium specimens and algal spores. - J. Phycol. 29: 381-384.

Gorton, H.L. \& Vogelman, T.C. (2003): Ultraviolet Radiation and the Snow Alga Chlamydomonas nivalis (Bauer) Wille. - Photochem. Photobiol. 77: 608-615.

Hanagata, N. (1998): Phylogeny of the subfamily Scotiellocystoideae (Chlorophyceae, Chlorophyta) and related taxa inferred from $18 \mathrm{~S}$ ribosomal RNA gene. - J. Phycol. 24: 1049-1054.

Helms, G.; Friedl, T.; Rambold, G. \& Mayrhofer, H. (2001): Identification of photobionts from the lichen family Physciaceae using algal-specific ITS rDNA sequences. - Lichenologist 33: 73-86.

Henderson, R.J.; Hegseth, E.N. \& Park, M.T. (1998): Seasonal variation in lipid and fatty acid composition of ice algae from the Barents Sea. - Polar Biol. 20: 48-55.

Hонам, R.W. (1975): The life history and ecology of the snow alga Chloromonas pichinchae (Chlorophyta, Volvocales). - Phycologia 14: 213-226.

Hoham, R.W. \& Mullet, J.E. (1977): The life history and ecology of the snow alga Chloromonas cryophila sp. nov. (Chlorophyta, Volvocales). - Phycologia 16: 53-68.

Hoham, R.W. \& Mullet, J.E. (1978): Chloromonas nivalis (Chod.) Hoh. \& Mull. comb. nov., and additional comments on the snow alga, Scotiella. - Phycologia 17: 106.

Hoham, R.W. \& Duval, B. (2001): Microbial ecology of snow and freshwater ice. - In: JONES, H.G.; POMEROY, J.W.; Walker, D.A. \& Hoham, R.W. (eds): Snow Ecology:
An Interdisciplinary Examination of Snow-Covered Ecosystems. - pp. 168-228, Cambridge University Press, Cambridge.

Hoham, R.W.; Mullet, J.E. \& Roemer, S.C. (1983): The life history and ecology of the snow alga Chloromonas polyptera comb. nov. (Chloropyta, Volvocales). Can. J. Bot. 61: 2416-2429.

Hoham, R.W.; Schlag, E.M.; Kang, J.Y.; Hasselwander, A.J.; Behrstock, A.F.; BlackbuRn, I.R.; Johnson, R.C. \& RoEmer, S.C. (1998): The effects of irradiance levels and spectral composition on mating strategies in the snow alga, Chloromonas sp.-D, from the Tughill Plateau, New York State. - Hydrol. Process. 12: $1627-1639$.

Hoham, R.W.; Bonome, T.A.; Martin, C.W. \& LeebensMACK, J.H. (2002): A combined 18S rDNA and $r b c \mathrm{~L}$ phylogenetic analyses of Chloromonas and Chlamydomonas (Chlorophyceae, Volvocales) emphasizing snow and other cold-temperature habitats. - J. Phycol. 38: 1051-1064.

Hoham, R.W.; Berman, J.D.; Rogers, H.S.; Felio, J.H.; RYbA, J.B. \& MiLleR, P.R. (2006): Two new species of green snow algae from Upstate New York, Chloromonas chenangoensis sp. nov. and Chloromonas tughillensis sp. nov. (Volvocales, Chlorophyceae) and the effects of light on their life cycle development. Phycologia 45: 319-330.

Hoham, R.W.; Filbin, R.W.; Frey, F.M.; Pusack, T.J.; Ryba, J.B.; McDermott, P.D. \& Fields, R.A.(2007): The Optimum $\mathrm{pH}$ of the green snow algae, Chloromonas tughillensis and Chloromonas chenangoensis, from Upstate New York. - Arct. Antarct. Alp. Res. 39: $65-73$.

HořickÁ, Z.; Stuchlík, E.; Hudec, I.; ČernÝ, M. \& FotT, J. (2006): Acidification and the structure of crustacean zooplankton in mountain lakes: The Tatra Mountains (Slovakia, Poland). - Biologia, 61/Suppl. 18: S121-S134.

Katana, A.; Kwiatowski, J.; Spalik, K.; Zakryś, B.; Szalacha, E. \& SzymaŃSKa, H. (2001): Phylogenetic position of Koliella (Chlorophyta) as inferred from nuclear and chloroplast small subunit rDNA. - J. Phycol. 37: 443-451.

Kates, M. \& Volcani, B.E. (1996): Biosynthetic pathways for phosphatidylsulfocholine, the sulfonium analogue of phosphatidylcholine, in diatoms. - In: Kiene, R.P.; Visscher, P.T.; Keller, M.D. \& Kirst, G.O. (eds): Biological and Environmental Chemistry of DMSP and Related Sulfonium Compounds. - pp. 109-119, Springer, New York.

Knothe, G. \& Dunn, R.O. (2009): A comprehensive evaluation of the melting points of fatty acids and esters determined by differential scanning calorimentry. J. Am. Oil Chem. Soc. 86: 843-856.

Kol, E. (1965): Roter Schnee von Scotiella in der Hohen Tátra. - Ann. Hist.-Nat. Mus. Natl. Hung. 57: 146-148.

KoL, E. (1968): Kryobiologie I. Kryovegetation. - In: ELSTER, J. \& OHLe, W. (eds): Die Binnengewasser 24. - 216 pp., Schweizerbart, Stuttgart.

Kol, E. (1970): Vom roten Schnee der Tiroler Alpen. - Ann. Hist.-Nat. Mus. Natl. Hung. 62: 129-136.

KoL, E. (1975a): Cryobiological researches in the High Tatra I. - Acta Bot. Hung. 21: 61-75.

KoL, E. (1975b): Cryobiological researches in the High Tatra 
II. - Acta Bot. Hung. 21: 279-287.

Koetschan, C.; Főrster, F.; Keller, A.; Schleicher, T.; Ruderisch, B.; Schwarz, R.; Müller, T.; Wolf, M. \& Schultz, J. (2010): The ITS2 Database III - sequences and structures for phylogeny. - Nucleic Acids Res. 38: D275-279.

KomÁReK, J. \& NedBalová, L. (2007): Green cryosestic algae. - In: SeckBaCh, J. (ed.): Algae and Cyanobacteria in Extreme Environments. - pp. 321-342, Springer, Dordrecht.

KoмÁromy, Z.P. (1982): Application of cluster analysis in the taxonomy of Scotiella species (Chlorophyceae). - Arch. Hydrobiol. Suppl. 60: 432-438.

KŘístek, Š.; Holuša, J.; Urbaňcová, N.; Trombik, J. \& DRÁPELA, K. (2011): Expeditionary measurements of snow in extensively forested Carpatian Mountains: evaluating parameters variability. - Carpath. J. Earth Environ. Sci. 6: 45-58.

KvíDERoví, J. (2010): Characterization of the community of snow algae and their photochemical performance in situ in the Giant Mountains, Czech Republic. - Arct. Antarct. Alp. Res., 42: 210-218.

Lang, I.; HodaČ, L.; FriedL, T. \& Feussner, I. (2011): Fatty acid profiles and their distribution patterns in microalgae: a comprehenive analysis of more than 2000 strains from the SAG culture collection. - BMC Plant Biol. 11: 124.

LinG, H.U. \& SePpelt, R.D. (1998): Snow algae of the Windmill Islands, continental Antarctica. 3. Chloromonas polyptera (Volvocales, Chlorophyta). - Polar Biol. 20: 320-324.

LuKAvSKÝ, J. (1994): Algal flora of lakes in the High Tatra Mts. (Slovakia). - Hydrobiologia: 274: 65-74.

Lukeš, M.; Procházková, L.; Shmidt, V.; Nedbalová, L. \& Kaftan, D. (2014): Temperature dependence of photosynthesis and thylakoid lipid composition in the red snow alga Chlamydomonas cf. nivalis (Chlorophyceae). - FEMS Microbiol. Ecol. 89: 303-315.

Lutz, S.; Anesio, A.M.; Edwards, A. \& Benning, L.G. (2015): Microbial diversity on Icelandic glaciers and ice caps. - Front Microbiol 6: 307.

LutZ, S.;ANesio,A.M.;RAISWELl, R.;EdWARdS,A.;Newton, R.J.; Gill, F. \& Benning, L. - G. (2016): The biogeography of red snow microbiomes and their role in melting arctic glaciers - Nat. Commun. 7: 11968, doi:10.1038/ncomms 11968 .

MatsuZaki, R.; Hara, Y. \& Nozaki, H. (2014): A taxonomic study of snow Chloromonas species (Volvocales, Chlorophyceae) based on light and electron microscopy and molecular analysis of cultured material. Phycologia 53: 293-304.

Matsuzaki, R.; KawaI-Toyooka, H.; Hara, Y. \& Nozaki, H. (2015): Revisiting the taxonomic significance of aplanozygote morphologies of two cosmopolitan snow species of the genus Chloromonas (Volvocales, Chlorophyceae). - Phycologia 54: 491-502.

Mikhailyuk, T.I.; Sluiman, H.J.; Massalski, A.; Mudimu, O.; Demchenko, E.M.; Kondratyuk, S.Y. \& Friedl, T. 2008. New streptophyte green algae from terrestrial habitats and an assessment of the genus Interfilum (Klebsormidiophyceae, Streptophyta). - J. Phycol. 44: 1586-1603.

Morgan-Kiss, R.; Ivanov, A.G.; Williams, J.; Khan, M. \& HUNER, N.P.A. (2006): Differential thermal effects on the energy distribution between photosystem II and photosystem I in thylakoid membranes of a psychrophilic and mesophilic alga. - Biochim. Biophys. Acta 1561: 251-265.

Müller, T.; Bleiß, W.; Martin, C.-D.; Rogaschewski, S. \& FuHR, G. (1998): Snow algae from northwest Svalbard: their identification, distribution, pigment and nutrient content. - Polar Biol. 20: 14-32.

NaKada, T.; ShinKawa, H.; Ito, T. \& Tomita, M. (2010): Recharacterization of Chlamydomonas reinhardtii and its relatives with new isolates from Japan. - J. Plant Res. 123: 67-78.

Novis, P. (2002): New records of snow algae for New Zealand, from the Mt Philistine, Arthur's Pass National Park. - New J. Zeal. Bot., 40: 297-312.

Ota, S.; Yoshihara, M.; YamaZaki, T.; TAKeshita, T.; Hirata, A.; Konomi, M.; Oshima, K., Hattorim, M.; Bišová, K.; ZaCHLEDER, V. \& KaWANO, S. (2016): Deciphering the relationship among phosphate dynamics, electron-dense body and lipid accumulation in the green alga Parachlorella kessleri. - Sci. Rep. 6: 25731, doi: 10.1038/srep25731.

Piercey-Normore, M. D. \& DePriest, P.T. (2001): Algalswitching among lichen symbioses. - Am. J. Bot. 88: 1490-1498

Remias, D. (2012): Cell structure and physiology of alpine snow and ice algae. - In: Lütz, C. (ed.): Plants in Alpine Regions. Cell Physiology of Adaption and Survival Strategies. - pp. 175-186, Springer, Wien.

Remias, D. \& LÜTZ, C. (2007): Characterisation of esterified secondary carotenoids and of their isomers in green algae: a HPLC approach. - Algological Studies 124: 85-94.

Remias, D.; Lütz-Meindl, U. \& Lütz, C. (2005): Photosynthesis, pigments and ultrastructure of the alpine snow alga Chlamydomonas nivalis. - Eur. J. Phycol. 40: 259-268.

Remias, D.; Karsten, U.; Lütz, C. \& Leya, T. (2010): Physiological and morphological processes in the Alpine snow alga Chloromonas nivalis (Chlorophyceae) during cyst formation. Protoplasma 243: 73-86.

Remias, D.; Wastian, H.; Lütz, C. \& LeYA, T. (2013): Insights into the biology and phylogeny of Chloromonas polyptera (Chlorophyta), an alga causing orange snow in Maritime Antarctica. - Antarct. Sci. 25: 648-656.

Remias, D.; Pichrtová, M.; Pangratz, M.; Lütz, C. \& Holzinger, A. (2016): Ecophysiology, secondary pigments and ultrastructure of Chlainomonas sp. (Chlorophyta) from the European Alps compared with Chlamydomonas nivalis forming red snow. FEMS Microbiol. Ecol. 92: fiw030.

Řezanka, T. (1990): Identification of very long polyenoic acids as picolinyl esters by $\mathrm{Ag}^{+}$ion-exchange highperformance liquid-chromatography, reversedphase high-performance liquid-chromatography and gas-chromatography mass-spectrometry. - J. Chromatogr. 513: 344-348.

Řezanka, T.; Nedbalová, L. \& Sigler, K. (2008): Unusual medium-chain polyunsaturated fatty acids from the snow alga Chloromonas brevispina. - Microbiol. Res. 163: 373-379.

Řezanka, T.; Nedbalová, L.; Procházková, L. \& Sigler, K. (2014): Lipidomic profiling of snow algae by ESI-MS 
and silver -LC/APCI-MS. - Phytochemistry 100: $34-42$.

SAunders, R.D. \& Horrocks, L.A. (1984): Simultaneous extraction and preparation for high-performance liquid chromatography of prostaglandins and phospholipids. - Anal. Biochem. 143: 71-75.

Spijkerman, E.; Wacker, A.; Weithoff, G. \& Leya, T. (2012): Elemental and fatty acid composition of snow algae in Arctic habitats. - Front. Microbiol. 3: 380.

Stibal, M. (2003): Ecological and physiological characteristics of snow algae from Czech and Slovak mountains. - Czech Phycology 3: 141-152.

Thompson, G.A. (1996): Lipids and membrane function in green algae. - Biochim. Biophys. Acta 1302: 17-45.

Vilgalys, R. \& Hester, M. (1990): Rapid genetic identification and mapping of enzymatically amplified ribosomal DNA from several Cryptococcus species. - J. Bacteriol. 172: 4238-4246.

WaLSBY, A.E. (1997): Modelling the daily integral of photosynthesis by phytoplankton: its dependence on the mean depth of the population. - Hydrobiologia 349: $65-74$.

Webb, W.L.; Newton, M. \& Starr, D. (1974): Carbon dioxide exchange of Alnus rubra. A mathematical model. - Oecologia 17: 281-291.

Wolf, M.; Chen, S.; Song, J.; Ankenbrand, M. \& Müller, T. (2013): Compensatory base changes in ITS2 secondary structres correlated with the biologic species concept despite intragenomic variability in ITS2 sequences - a proof of concept. - PLOS ONE 8: e66726.

ZASADNi, J. \& KŁAPYTA, P. (2014): The Tatra Mountains during the Last Glacial Maximum. - J. Maps 10: 440-456.

Zuker, D.J. (2003): Mfold web server for nucleic acid folding and hybridization prediction. - Nucleic Acids Res. 31: 3406-3415.

Supplementary material

the following supplementary material is available for this article:

Table S1. Collection data and sample codes of mature aplanozygotes of Chloromonas nivalis from exposed snow fields in the Austrian Alps.

Fig S1. Comparison of lengths of mature aplanozygotes between Chloromonas nivalis subsp. tatrae (LP01) and Chloromonas nivalis from the Austrian Alps (P12, P24/DR4, DR43, GK05, GK09)

Fig S2-S4. Comparison of lengths, widths and length to width ratio (L:W) of mature aplanozygotes between Chloromonas nivalis subsp. tatrae (one sample) and Chloromonas nivalis from the Austrian Alps (five samples).

This material is available as part of the online article (http:// fottea.czechphycology.cz/contents)

(C) Czech Phycological Society (2018)

Received January 26, 2017

Accepted March 15, 2017 